\title{
Origin, properties and transformation of soil lamellae in rusty soils (Brunic Arenosols) in southeastern Poland
}

\author{
Magdalena Gus-Stolarczyk ${ }^{1 *}$, Marek Drewnik ${ }^{1}$, Wojciech Szymański ${ }^{1}$ \\ ${ }^{1}$ Jagiellonian University, Faculty of Geography and Geology, Institute of Geography and Spatial Management, Department of Pedology and Soil \\ Geography, ul. Gronostajowa 7, 30-387 Kraków, Poland \\ * M. Gus-Stolarczyk, MSc, magdalena.gus@uj.edu.pl, ORCID iD: https://orcid.org/0000-0001-9560-7937
}

\begin{abstract}
Received: 19.06.2021

Accepted: 11.11 .2021

Associated editor: Ł. Uzarowicz

Keywords
Sandy soils
Siderik horizon
Soil genesis
Micromorphology
Illuviation

\section{Keywords}

Micromorphology

Illuviation

Lamellae represent a form of illuvial accumulation of the clay fraction commonly found in Quaternary sands. Despite great interest in soils in which lamellae occur, the origin, properties and transformation of lamellae are still not fully understood. In addition, research on lamellae in sandy material was carried out mainly in Podzols, ochre soils (Rubic Arenosols) and Arenosols, while no research was conducted in this respect in rusty soils (Brunic Arenosols). The main aim of the present study was to explain lamellae origin and transformation on the example of rusty soils (Brunic Arenosols) in southeastern Poland basing on their morphology, physical and chemical properties and using micromorphological studies. The research work was performed in southeastern Poland (Kraków Gate region and Central Beskid Foothills) at the research sites Kostrze, Gołęczyna, and Połomia. The parent material of the studied soils was glaciofluvial sands. Soil lamellae in the studied rusty soils exhibit high diversity in terms of morphology and physical and chemical properties. They are characterized by a higher content of fine fractions $(<0,05 \mathrm{~mm})$, total organic carbon and non-silicate iron and aluminum compared to interlamellae. A number of morphological and micromorphological features, such as the presence of clay-iron coatings on mineral grains serve as evidence of the pedo-petrogenic nature of lamellae. In the uppermost parts of rusty soils, lamellae show a high degree of degradation, mainly due to biological activity.
\end{abstract}

\section{Introduction}

Sandy soils found in different natural environments commonly contain fine-textured illuvial forms referred to as lamellae (Schaetzl, 1992; Rawling, 2000; Holliday and Rawling, 2006; Bockheim and Hartemink, 2013). Soil lamellae are thin layers of clay-enriched material (Gile, 1979) associated with iron oxides (Prusinkiewicz et al., 1998; Lisá et al., 2019) and are characterized by finer texture (Schaetzl, 1992; Bockheim and Hartemink, 2013) and more intensive, redder color (Van Reeuwijk and de Villiers, 1985) than interlamellae material. Lamellae serve as soil stratigraphic markers and relative age indicators in geomorphologic and archeological studies (Gile, 1979; Miles and Franzmeier, 1981; Prusinkiewicz et al., 1998; Holliday and Rawling, 2006).

Reviews of lamellae origin (Rawling, 2000) indicate two main, different ways of their formation. In majority of sandy soils, a pedogenic concept prevails in the literature as the main formation pathway, which is evidenced by the increase of lamellae expression over time (Gile, 1979; Van Reeuwijk and de Villiers, 1985; Holliday and Rawling, 2006; Johnson et al., 2008), intersecting bedding planes (Dijkerman et al., 1967; Prusinkiewicz et al., 1994), content of illuvial clay coatings on quartz grains and bridges between them (Van Reeuwijk and de Villiers, 1985; Kemp and McIntosh, 1989; Schaetzl, 2001) and occurrence of lamellae in the soil solum (and usually absence in parent material) (Holliday and Rawling, 2006). In turn, petrogenic lamellae are sedimentary features, which occur parallel to bedding planes and occur at great depths (Dijkerman et al., 1967; Robinson and Rich, 1960; Muhs, 2017). The formation of such lamellae may be 1) the result of the cyclic sedimentation of fine material in the course of the accumulation of deposits (Bullock and Mackney, 1970; Boubaid et al., 1992) or 2) the result of break-up of silt/ clay aggregates deposited primarily in laminae and the dispersion of clay throughout laminae (Kilibarda et al. 2008). Except for the abovementioned views, a polygenesis of the described forms has also been identified, characterized by both geologic and pedologic factors (Rawling, 2000). The number of case studies describing pedo-petrogenic lamellae origin has increased in the last few decades (Coen et al., 1966; Gile, 1979; Boubaid et al., 1992; Soil Survey Staff, 1999; Rawling, 2000; Schaetzl, 2001; Kilibarda et al., 2008; Jankowski, 2012; Obear et al., 2017).

Most of the studies are related to lamellae origin and mechanisms of their formation, but only a few raise the issue of the transformation of lamellae in the soil profile (Kemp and 
McIntosh, 1989; Johnson et al., 2008; Bockheim and Hartemink, 2013). The most common factors of lamellae transformation are bioturbation caused by root growth and soil fauna activity (Kemp and McIntosh, 1989; Johnson et al., 2008). Other examples of the mechanical transformation of lamellae are freeze-thaw and drying-wetting cycles (Bryant, 1982; Kemp and McIntosh, 1989). For instance, Bryant (1982) notes the impact of permafrost and inhibition of drainage in the lower part of soil profile on lamellae breakdown. In turn, Bockheim and Hartemink (2013) note biogeochemical processes occurring in the soil as a probable transformation factor of lamellae. In tropical regions lamellae are described as forms resulting from the degradation of Bt horizons, however, as some authors describe (Furquim et al., 2013) the ongoing process of eluviation may contribute to lamellae disappearance. The above studies indicate that lamellae transformation can be observed frequently. However, there is still a lack of studies focused on the direct impact of in situ chemical weathering as a main transformation factor of soil lamellae.

Lamellae commonly occur in rusty soils (Brunic Arenosols) around the world (Prusinkiewicz et al., 1998; Jankowski, 2012; Bockheim and Hartemink, 2013; Phillips et al., 2015; Kruczkowska et al., 2020), which are soils typically found in post-glacial areas in temperate climates. Rusty soils (Brunic Arenosols) develop mainly from glaciofluvial, sandy deposits enriched in aluminosilicate minerals. In these soils, so-called siderik Bv horizon according to the Polish Soil Classification (2019) or cambic Bw horizon according to the IUSS Working Group WRB (2015) with features of pedogenic accumulation of iron and aluminum oxides occur below the humus horizon. In international soil classification rusty soils are classified as Brunic Arenosols (IUSS Working Group WRB, 2015). In Polish Soil Classification (2019) rusty soils (Brunic Arenosols) yield a separate typological unit. Polish studies on rusty soils (Brunic Arenosols) have been performed in central and north Poland (Kowalkowski, 1977; Bednarek, 1991; Janowska, 1994; 2001; Manikowska and Bednarek, 1994; Prusinkiewicz et al., 1994; 1998; Bednarek et al., 2010; Chojnicki and Piotrowska, 2010; Jankowski et al., 2011; Jankowski, 2012), in the Roztocze region (Uziak et al., 2010), Lower Silesia region (Kabała, 2005), and in mountain areas (Kowalkowski and Degórski, 2005; Marzec and Kabała, 2008). However, there is a lack of studies on rusty soils (Brunic Arenosols) in southeastern Poland.

Studies on lamellae in sandy soils was carried out mainly in Podzols, ochre soils (Rubic Arenosols), and Arenosols. In rusty soils (Brunic Arenosols) a relatively finer (sandy) texture may lead to translocation and accumulation of the clay fraction in the form of thin soil lamellae (Polish Soil Classification, 2019). Although soil lamellae are often found in rusty soils (Brunic Arenosols), there is little research work devoted to their origin, transformation, and properties. Thus, the main aim of the present study was to explain lamellae origin and transformation on the example of rusty soils (Brunic Arenosols) in southeastern Poland basing on their morphology, physical and chemical properties and using micromorphological studies.

\section{Materials and methods}

\subsection{Study area}

The study was carried out in southeastern Poland at three study sites - Kostrze, Gołęczyna and Połomia. Three soil profiles: L1, L2 and L3, respectively, were selected for the study. The study areas were located in the so-called Kraków Gate area (Kostrze site) and in the Central Beskids Foothills (Gołęczyna and Połomia sites). The soil parent material in all the study sites consisted of sandy glaciofluvial deposits (Rutkowski, 1993; Gradziński and Gradziński, 2013; Marciniec and Zimnal, 2016). All the studied sites were characterized by a mean annual air temperature ca. $6-8^{\circ} \mathrm{C}$ and mean annual precipitation ranging from 650 to 750 mm (Obrębska-Starklowa et al., 1995; Bokwa et al., 2015). The community of Nardo-Callunetea, with predominance of grasses, heather, and silver birch (Betula pendula) was located at the Kostrze study site. The Gołęczyna and Połomia sites are located under mixed forests with a prevalence of Scots pine (Pinus sylvestris), hornbeam (Carpinus betulus), and an admixture of beech (Fagus sylvatica). Detailed information about the study sites is listed in Table 1.

\subsection{Field and laboratory studies}

The studied soils were described and sampled according to the FAO Guidelines for Soil Description (Jahn et al., 2006). Samples from horizons where lamellae occur were collected separately from lamellae and interlamellae. A detailed description of lamellae morphology including depth of occurrence, thickness, continuity, color, shape, pattern, and boundaries was performed. Undisturbed soil samples were collected for micromorphological analysis from selected horizons (Bv, BC, and parent material). Soil color was determined in the moist state using Munsell Soil Color Charts (Munsell, 1975).

Table 1

Location and site characteristic

\begin{tabular}{|c|c|c|c|c|c|c|}
\hline No & Site & GPS coordinates & Elevation $\mathrm{m}$ a.s.l. & Parent material & Geomorphic position & Vegetation \\
\hline L1 & Kostrze & $\begin{array}{l}50^{\circ} 02^{\prime} 08^{\prime \prime} \mathrm{N} \\
19^{\circ} 52^{\prime} 10^{\prime \prime} \mathrm{E}\end{array}$ & 226 & Glaciofluvial sands & Gentle slope $\left(3-5^{\circ}\right)$; aspect $N$ & Heath \\
\hline L2 & Gołęczyna & $\begin{array}{l}49^{\circ} 58^{\prime} 29^{\prime \prime} \mathrm{N} \\
21^{\circ} 20^{\prime} 88^{\prime \prime} \mathrm{E}\end{array}$ & 258 & Glaciofluvial sands & Gentle slope $\left(0-3^{\circ}\right)$; aspect $\mathrm{NE}$ & Mixed forest \\
\hline L3 & Połomia & $\begin{array}{l}49^{\circ} 58^{\prime} 16^{\prime \prime} \mathrm{N} \\
21^{\circ} 22^{\prime} 45^{\prime \prime} \mathrm{E}\end{array}$ & 356 & Glaciofluvial sands & Gentle slope $\left(0-3^{\circ}\right)$; aspect SW & Mixed forest \\
\hline
\end{tabular}


Collected samples were air-dried, gently crushed and sieved through a $2 \mathrm{~mm}$ steel sieve. Living roots were removed from the soil samples. The particle-size distribution was determined using a laser diffraction method employing a Mastersizer 3000 granulometer, with dispersion in distilled water and ultrasounds. The soil mineral composition was determined for selected soil horizons via X-ray powder diffraction (XRD) on a Rigaku MiniFlex600 benchtop diffractometer. Random powder specimens were analyzed from 2 to $65^{\circ} 2 \theta$ at a counting speed of $0.02^{\circ} / 1 \mathrm{~s}$. Total carbon concentration was determined via gas chromatography using a micro-analyzer with simultaneous CHN determination via a vario MICRO cube (Nelson and Sommers, 1996). Due to the absence of carbonates in the studied soils, the total carbon content corresponds to the total organic carbon (TOC) content. Soil $\mathrm{pH}$ was measured potentiometrically in distilled water using a 1:1 ratio (Thomas, 1996).

The concentration of total iron and non-silicate forms of both iron and aluminum in the selected soil horizons was determined using flame atomic absorption spectroscopy (Agilent FS F-AAS). In order to determine the total content of iron $\left(\mathrm{Fe}_{\mathrm{t}}\right)$, $0.5 \mathrm{~g}$ of sample were mineralized in an acid mixture consisting of $\mathrm{HNO}_{3}, \mathrm{HCl}$, and $\mathrm{HF}$ (2-6-2 $\mathrm{ml}$ ratio) via microwave assisted digestion. The „free” iron $\left(\mathrm{Fe}_{d}\right)$ was extracted with a citrate- -bicarbonate-dithionite (CBD) solution (Mehra and Jackson, 1960). The amorphous forms of iron $\left(\mathrm{Fe}_{0}\right)$ and aluminum $\left(\mathrm{Al}_{0}\right)$ were extracted using a solution of acid ammonium oxalate (Van Reeuwijk, 2002). The $\mathrm{Al}_{\mathrm{o}}+1 / 2 \mathrm{Fe}_{0}$ index was then calculated, as were the weathering index for iron $\left(\mathrm{Fe}_{\mathrm{d}} / \mathrm{Fe}_{\mathrm{t}}\right)$ and iron activity ratio $\left(\mathrm{Fe}_{\mathrm{o}} / \mathrm{Fe}_{\mathrm{d}}\right)$ (Schwertmann, 1964).

Micromorphological analysis was performed on thin sections prepared according to the standard procedures described in the literature (FitzPatrick, 1984) via a polarizing microscope (Nikon Eclipse E600 POL). For micromorphological descriptions, terminology given by Stoops (2003) was used.

The studied soils were classified according to the sixth edition of the Polish Soil Classification (2019) and the WRB system (IUSS Working Group WRB 2015).

\section{Results}

\subsection{Soil and lamellae morphology}

The studied soils exhibited morphologic differences (Table 2, Fig. 1). One of the studied soils (profile L1 - Dystric Lamellic Brunic Arenosol (Ochric)) was characterized by the

Table 2

Morphology and classification of the studied soils

\begin{tabular}{|c|c|c|c|c|c|c|c|}
\hline \multirow[t]{2}{*}{ Horizon } & Depth & \multirow[t]{2}{*}{ Lamellae/ interlamellae } & Munsell color & \multirow[t]{2}{*}{ Structure* } & \multirow[t]{2}{*}{ Roots } & \multirow[t]{2}{*}{ Consistence $^{* *}$} & \multirow[t]{2}{*}{ Horizon boundary } \\
\hline & $\mathrm{cm}$ & & moist & & & & \\
\hline \multicolumn{8}{|c|}{ L1 Brown-rusty soil (proto-lamellar) (PSC 2019); Dystric Lamellic Brunic ARENOSOL (Ochric) (WRB 2015) } \\
\hline Of & $4-0$ & - & n.a. & n.a. & n.a. & & abrupt \\
\hline A & $0-14$ & - & 10YR $2 / 1$ & SA & many & SO & clear wavy \\
\hline $\mathrm{Bv}^{* * *}$ & $14-40$ & - & 10YR 4/4 & SA & common & SHA & clear smooth \\
\hline \multirow[t]{2}{*}{$\mathrm{BC} 1$} & $40-60$ & INTERLAMELLAE & 10YR 5/4 & $\mathrm{SA}, \mathrm{SG}$ & few & SHA & clear wavy \\
\hline & & LAMELLAE & 10YR 5/6 & & & & \\
\hline \multirow[t]{2}{*}{$\mathrm{BC} 2$} & $60-95$ & INTERLAMELLAE & 10YR 5/4 & SG & very few & SHA & gradual \\
\hline & & LAMELLAE & 10YR 5/8 & & & & \\
\hline \multirow[t]{2}{*}{$\mathrm{C} 1$} & $95-130$ & INTERLAMELLAE & 10YR 5/4 & $\mathrm{SA}, \mathrm{AB}, \mathrm{SG}$ & very few & SHA & gradual \\
\hline & & LAMELLAE & $7.5 Y R \quad 4 / 6$ & & & & \\
\hline \multirow[t]{2}{*}{$\mathrm{C} 2$} & $130-160$ & INTERLAMELLAE & 10YR 6/3 & $\mathrm{SA}, \mathrm{AB}, \mathrm{SG}$ & very few & SHA & gradual \\
\hline & & LAMELLAE & $7.5 Y R \quad 4 / 6$ & & & & \\
\hline \multirow[t]{2}{*}{$\mathrm{C} 3$} & $160-(200)$ & INTERLAMELLAE & 10YR 6/3 & $\mathrm{SA}, \mathrm{AB}, \mathrm{SG}$ & very few & SHA & - \\
\hline & & LAMELLAE & $7.5 Y R \quad 4 / 6$ & & & & \\
\hline
\end{tabular}

L2 Podzolic brown-rusty soil (proto-lamellar) (PSC 2019); Dystric Lamellic Brunic ARENOSOL (Ochric, Protospodic) (WRB 2015)

\begin{tabular}{|c|c|c|c|c|c|c|c|}
\hline $\mathrm{Ol}$ & $2-0$ & - & n.a. & n.a. & n.a. & n.a. & n.a. \\
\hline C & $0-10$ & - & $2.5 Y 3 / 3$ & SA, GR, SG & many & SO & clear smooth \\
\hline A & $10-20$ & - & $2.5 Y 4 / 3$ & SA, GR & many & SO & clear wavy \\
\hline $\mathrm{E}$ & $20-25$ & - & $2.5 \mathrm{Y} 4 / 2$ & GR, SG & common & SO & clear wavy \\
\hline Bs & $25-35$ & - & 10YR 4/6 & $\mathrm{SA}, \mathrm{AB}$ & common & SHA & clear wavy \\
\hline $\mathrm{Bv}$ & $35-60$ & - & 10YR 4/4 & $\mathrm{SA}, \mathrm{AB}$ & common & SHA & gradual \\
\hline $\mathrm{BC}$ & $60-85$ & - & 10YR 5/4 & SG & common & SO & gradual \\
\hline \multirow[t]{2}{*}{$\mathrm{C} 1$} & $85-130$ & INTERLAMELLAE & $2.5 Y 4 / 4$ & SG & few & SHA & gradual \\
\hline & & LAMELLAE & 10YR 3/6 & & & & \\
\hline \multirow[t]{2}{*}{$\mathrm{C} 2$} & 130-(190) & INTERLAMELLAE & $2.5 \mathrm{Y} 4 / 4$ & SG & few & SHA & - \\
\hline & & LAMELLAE & 10YR 4/4 & & & & \\
\hline
\end{tabular}


Table 2, continue

\begin{tabular}{|c|c|c|c|c|c|c|c|}
\hline \multirow[t]{2}{*}{ Horizon } & Depth & \multirow[t]{2}{*}{ Lamellae/ interlamellae } & Munsell color & \multirow[t]{2}{*}{ Structure* } & \multirow[t]{2}{*}{ Roots } & \multirow[t]{2}{*}{ Consistence** } & \multirow[t]{2}{*}{ Horizon boundary } \\
\hline & $\mathrm{cm}$ & & moist & & & & \\
\hline \multicolumn{8}{|c|}{ L3 Podzolic brown-rusty soil (humic, covered) (PSC 2019); Dystric Brunic ARENOSOL (Humic, Areninovic) (WRB 2015) } \\
\hline $\mathrm{Ol}$ & $4-0$ & - & n.a. & n.a. & n.a. & n.a. & n.a. \\
\hline A & $0-8$ & - & $7.5 Y R 3 / 3$ & GR & many & LO & clear wavy \\
\hline $\mathrm{E}$ & $8-16$ & - & 10YR 4/2 & SG & few & so & clear irregular \\
\hline $\mathrm{BC}$ & $16-40$ & - & 10YR 4/6 & $\mathrm{SG}, \mathrm{SA}$ & few & SHA & clear irregular \\
\hline $\mathrm{Ab}$ & $40-60$ & - & 10YR $3 / 3$ & GR & many & HA & clear wavy \\
\hline $\mathrm{AE}$ & $60-75$ & - & 10YR $4 / 2$ & SG & common & HA & clear wavy \\
\hline Bvb & $75-110$ & - & 10YR 5/6 & SA & common & SHA & clear wavy \\
\hline \multirow[t]{2}{*}{$\mathrm{C} 1$} & $110-133$ & INTERLAMELLAE & 10YR 6/6 & SG & few & SHA & gradual \\
\hline & & LAMELLAE & 7.5YR $4 / 4$ & & & & \\
\hline \multirow[t]{2}{*}{$\mathrm{C} 2$} & 133-(200) & INTERLAMELLAE & 10YR 6/4 & SG & few & SHA & - \\
\hline & & LAMELLAE & 7.5YR 3/4 & & & & \\
\hline
\end{tabular}

*Structure: SG - single grain, SA - subangular blocky, AB - angular blocky, GR - granular; **Consistence: LO - loose, SO - soft, SHA-slightly hard, HA-hard; ${ }^{* * *} \mathrm{Bv}$ - siderik horizons (according to the PSC (2019)) with the change of the color of the sand due to the pedogenic accumulation of iron and aluminum oxides; n.a. - not analyzed

Fig. 1. Location of study area and studied pedons. Morphology of studied rusty soils (Brunic Arenosols). Siderik Bv horizons (according to the Polish Soil Classification (2019)) with the change of the color of the sand due to the pedogenic accumulation of iron and aluminum oxides
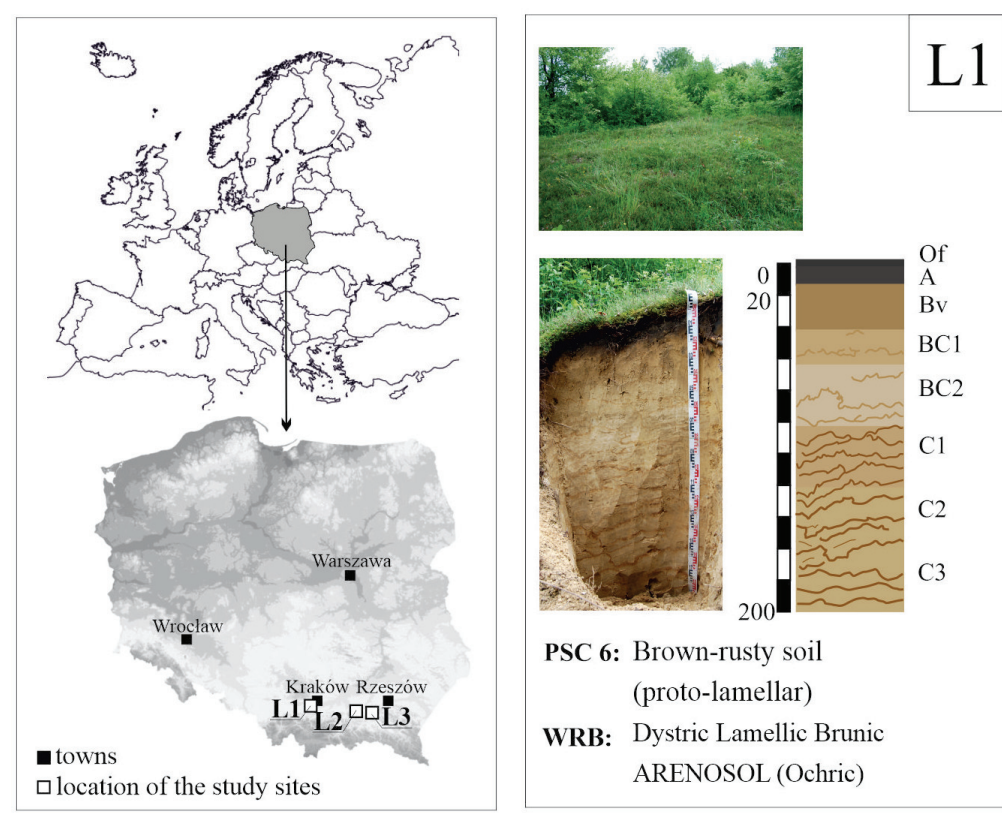

PSC 6: Brown-rusty soil (proto-lamellar)

WRB: Dystric Lamellic Brunic ARENOSOL (Ochric)

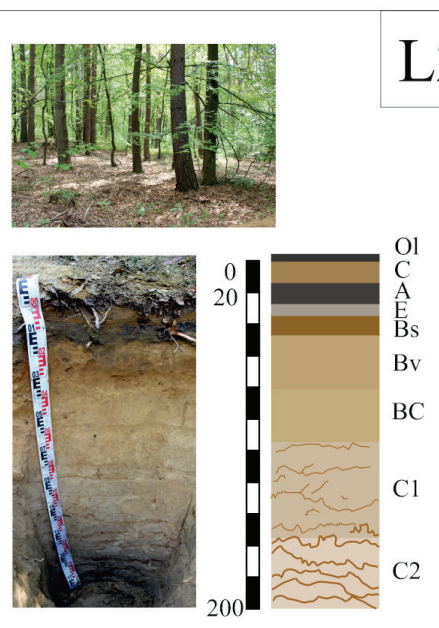

PSC 6: Podzolic brown-rusty soil (proto-lamellar)

WRB: Dystric Lamellic Brunic ARENOSOL (Ochric, Protospodic)

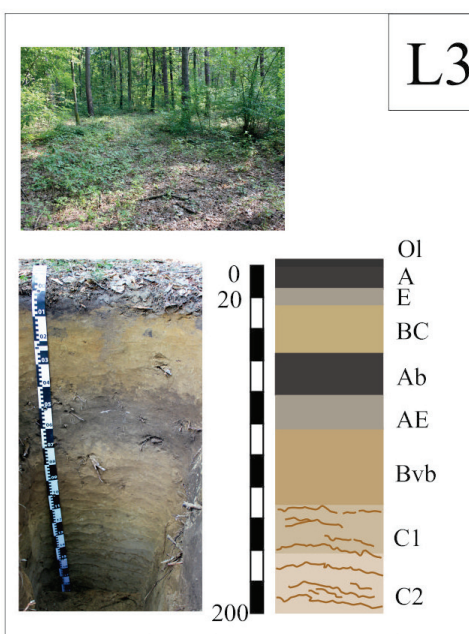

PSC 6: Podzolic brown-rusty soil (humic, covered)

WRB: Dystric Brunic ARENOSOL (Humic, Areninovic) 
occurrence of a sequence of soil horizons typical of rusty soils (Brunic Arenosols): O-A-Bv-C. A thick humus horizon $(14 \mathrm{~cm})$ with subangular blocky structure, soft consistence, and clear wavy boundary to the Bv horizon occurred beneath the organic $\mathrm{O}$ horizon in profile L1. Relatively thick $(26 \mathrm{~cm})$ siderik Bv horizon was characterized by brownish yellow color (10YR 6/6), subangular blocky structure, and slightly hard consistence. A transitional BC horizon with single grain structure was found below. Roots mostly occurred in the upper part of the solum. In profile L2 (Dystric Lamellic Brunic Arenosol (Ochric, Protospodic)) (Table 2), sandy material labelled as $C$ occurred below the organic $\mathrm{O}$ horizon. A humus horizon was found below the $10 \mathrm{~cm}$ layer of sandy material. An eluvial E horizon with eluviation features (olive-brown color 2.5Y 4/2) occurred above the Bs horizon and thick $(25 \mathrm{~cm})$ siderik Bv horizon. Roots occurred in most parts of this soil profile. The uppermost part of profile L3 (see Table 2) consisted of a sequence of A-E-BC horizons with loose and soft consistence and single-grain structure. Below buried soil with a sequence of soil horizons typical of rusty soils (Brunic Arenosols): Ab-AE-Bvb-C occurred. The entire L3 profile (Dystric
Brunic Arenosol (Humic, Areninovic)) was characterized by the predominance of single-grain structure, with the exception of siderik and humus horizons, which had a subangular blocky and granular structure, respectively. Hard and slightly hard consistence was identified in the buried soil. Roots commonly occurred in $\mathrm{A}, \mathrm{Ab}$ and $\mathrm{Bvb}$ horizons.

Soil lamellae appeared almost throughout the entire L1 profile (Table 3), except for the Bv and A horizons. Lamellae were first observed at a depth of $40 \mathrm{~cm}$ down to a depth of $95 \mathrm{~cm}$. They were mostly thin, discontinuous, and yellowish brown in color (10YR 5/6). In parent material the soil lamellae were thicker (up to $50 \mathrm{~mm}$ ), continuous, and redder (7.5YR 4/6). Below $130 \mathrm{~cm}$ their boundaries were sharp and clear, while in the upper parts of the soil profile their boundaries were ragged and blurry. In the whole L1 profile, soil lamellae followed a wavy and irregular shape, and mostly horizontal and vertical course in the profile. The thickness of interlamellae was similar in all the studied horizons and ranged from 50 to $200 \mathrm{~mm}$. In turn, in the L2 and L3 profiles (Table 3), soil lamellae occurred only in parent material and were characterized by mostly wavy and irregular shape,

Table 3

Morphology of soil lamellae

\begin{tabular}{|c|c|c|c|c|c|c|c|c|}
\hline \multirow[t]{2}{*}{ Horizon } & Depth & Thickness & Continuity & $\begin{array}{l}\text { Munsell color } \\
\text { in moist state }\end{array}$ & Shape of lamellae & Course in soil profile & Boundaries & $\begin{array}{l}\text { Thickness of } \\
\text { interlamellae }\end{array}$ \\
\hline & $\mathrm{cm}$ & $\mathrm{mm}$ & & & & & & $\mathrm{mm}$ \\
\hline
\end{tabular}

L1 Brown-rusty soil (proto-lamellar) (PSC 2019); Dystric Lamellic Brunic ARENOSOL (Ochric) (WRB 2015)

\begin{tabular}{|c|c|c|c|c|c|c|c|c|}
\hline A & $0-14$ & \multicolumn{7}{|c|}{ lack of soil lamellae } \\
\hline $\mathrm{Bv}$ & $14-40$ & \multicolumn{7}{|c|}{ lack of soil lamellae } \\
\hline $\mathrm{BC} 1$ & $40-60$ & $2-3$ & discontinuous & 10YR 5/6 & wavy, irregular & horizontal and vertical & ragged, blurry & $50-100$ \\
\hline $\mathrm{BC} 2$ & $60-95$ & $3-7$ & mixed & 10YR 5/8 & wavy, irregular & horizontal and vertical & ragged, blurry & $50-200$ \\
\hline $\mathrm{C} 1$ & $95-130$ & $1-50$ & continuous & 7.5YR $4 / 6$ & wavy, irregular & horizontal & ragged, blurry & $50-200$ \\
\hline $\mathrm{C} 2$ & $130-160$ & $1-50$ & continuous & 7.5YR $4 / 6$ & wavy, irregular & horizontal and vertical & sharp, clear & $50-200$ \\
\hline $\mathrm{C} 3$ & $160-(200)$ & $1-50$ & continuous & $7.5 Y R 4 / 6$ & wavy, irregular & horizontal & sharp, clear & 50-200 \\
\hline
\end{tabular}

L2 Podzolic brown-rusty soil (proto-lamellar) (PSC 2019); Dystric Lamellic Brunic ARENOSOL (Ochric, Protospodic) (WRB 2015)

C $\quad$ 0-10 lack of soil lamellae

A 10-20 lack of soil lamellae

E 20-25 lack of soil lamellae

Bs 25-35 lack of soil lamellae

Bv 35-60 lack of soil lamellae

BC 60-85 fragmented parts of soil lamellae

C1 85-130 2-10 discontinuous 10YR 3/6 wave-150

C2 130-(190) 5-30 continuous 10YR 4/4 wavy, irregular horizontal

L3 Podzolic brown-rusty soil (humic, covered) (PSC 2019); Dystric Brunic ARENOSOL (Humic, Areninovic) (WRB 2015)

\begin{tabular}{|c|c|c|c|c|c|c|c|}
\hline A & $0-8$ & lack of soil lamellae & & & & & \\
\hline $\mathrm{E}$ & $8-16$ & lack of soil lamellae & & & & & \\
\hline $\mathrm{BC}$ & $16-40$ & lack of soil lamellae & & & & & \\
\hline $\mathrm{Ab}$ & $40-60$ & lack of soil lamellae & & & & & \\
\hline $\mathrm{AE}$ & $60-75$ & lack of soil lamellae & & & & & \\
\hline Bvb & $75-110$ & lack of soil lamellae & & & & & \\
\hline $\mathrm{C} 1$ & $110-133$ & mixed & 7.5YR $4 / 4$ & wavy, irregular & horizontal & sharp, clear & 10-180 \\
\hline $\mathrm{C} 2$ & 133-(200) & continuous & 7.5YR 3/4 & straight, irregular & horizontal & sharp, clear & $10-180$ \\
\hline
\end{tabular}


horizontal course, sharp and clear boundaries, and were either continuous or continuous and discontinuous at the same site. Only in the $\mathrm{C} 1$ horizon in the L2 profile lamellae were discontinuous with ragged and blurry boundaries. In the BC horizon in the L2 profile lamellae occurred fragmentarily. The thickness of the studied interlamellae varied from 10 to $180 \mathrm{~mm}$.

\subsection{Physical and chemical properties, and mineral composition}

The texture of all the studied soils was fine sand, loamy fine sand or sandy loam (Table 4). The soil lamellae usually had a somewhat finer texture and were characterized by higher silt

Table 4

Physical and chemical properties of the studied soils

\begin{tabular}{|c|c|c|c|c|c|c|c|c|}
\hline \multirow[t]{2}{*}{ Horizon } & \multirow{2}{*}{$\begin{array}{l}\text { Depth } \\
\mathrm{cm}\end{array}$} & \multirow[t]{2}{*}{ Lamellae/ interlamellae } & \multicolumn{3}{|c|}{ Content (\%) in fine fraction } & \multirow{2}{*}{$\begin{array}{l}\text { Texture (IUSS WRB } \\
\text { 2015) }\end{array}$} & \multirow{2}{*}{$\frac{\mathrm{pH}}{\mathrm{H}_{2} \mathrm{O}}$} & \multirow{2}{*}{$\begin{array}{l}\mathrm{TOC} \\
\%\end{array}$} \\
\hline & & & sand & silt & clay & & & \\
\hline \multicolumn{9}{|c|}{ L1 Brown-rusty soil (proto-lamellar) (PSC 2019); Dystric Lamellic Brunic ARENOSOL (Ochric) (WRB 2015) } \\
\hline Of & $4-0$ & - & n.a. & n.a. & n.a. & n.a. & 4.3 & 23.25 \\
\hline A & $0-14$ & - & 77 & 22 & 1 & loamy fine sand & 4.8 & 1.16 \\
\hline $\mathrm{Bv}$ & $14-40$ & - & 85 & 14 & 2 & loamy fine sand & 5.4 & 0.19 \\
\hline \multirow[t]{2}{*}{$\mathrm{BC} 1$} & $40-60$ & INTERLAMELLAE & 76 & 23 & 2 & loamy fine sand & 5.3 & 0.13 \\
\hline & & LAMELLAE & 77 & 21 & 2 & loamy fine sand & 5.2 & 0.15 \\
\hline \multirow[t]{2}{*}{$\mathrm{BC} 2$} & $60-95$ & INTERLAMELLAE & 78 & 20 & 2 & loamy fine sand & 5.3 & 0.08 \\
\hline & & LAMELLAE & 65 & 32 & 3 & sandy loam & 5.2 & 0.13 \\
\hline \multirow[t]{2}{*}{$\mathrm{C} 1$} & $95-130$ & INTERLAMELLAE & 74 & 24 & 2 & loamy fine sand & 5.4 & 0.08 \\
\hline & & LAMELLAE & 63 & 33 & 4 & sandy loam & 5.5 & 0.13 \\
\hline \multirow[t]{2}{*}{$\mathrm{C} 2$} & $130-160$ & INTERLAMELLAE & 85 & 13 & 2 & loamy fine sand & 5.4 & 0.07 \\
\hline & & LAMELLAE & 68 & 28 & 4 & sandy loam & 5.5 & 0.10 \\
\hline \multirow[t]{2}{*}{$\mathrm{C} 3$} & $160-(200)$ & INTERLAMELLAE & 82 & 16 & 2 & loamy fine sand & 5.5 & 0.13 \\
\hline & & LAMELLAE & 66 & 30 & 4 & sandy loam & 5.5 & 0.08 \\
\hline \multicolumn{9}{|c|}{ L2 Podzolic brown-rusty soil (proto-lamellar) (PSC 2019); Dystric Lamellic Brunic ARENOSOL (Ochric, Protospodic) (WRB 2015) } \\
\hline $\mathrm{Ol}$ & $2-0$ & - & n.a. & n.a. & n.a. & n.a. & 4.8 & 35.86 \\
\hline C & $0-10$ & - & 94 & 2 & 4 & fine sand & 4.6 & 0.81 \\
\hline A & $10-20$ & - & 95 & 4 & 1 & fine sand & 4.4 & 1.07 \\
\hline $\mathrm{E}$ & $20-25$ & - & 97 & 3 & 0 & fine sand & 4.6 & 0.33 \\
\hline Bs & $25-35$ & - & 86 & 12 & 2 & loamy fine sand & 4.7 & 0.47 \\
\hline $\mathrm{Bv}$ & $35-60$ & - & 85 & 13 & 2 & loamy fine sand & 4.6 & 0.20 \\
\hline $\mathrm{BC}$ & $60-85$ & - & 97 & 3 & 0 & fine sand & 4.8 & 0.19 \\
\hline \multirow[t]{2}{*}{$\mathrm{C} 1$} & 85-130 & INTERLAMELLAE & 97 & 3 & 0 & fine sand & 5.1 & 0.19 \\
\hline & & LAMELLAE & 86 & 12 & 2 & loamy fine sand & 5.2 & 0.16 \\
\hline \multirow[t]{2}{*}{$\mathrm{C} 2$} & 130-(190) & INTERLAMELLAE & 97 & 2 & 1 & fine sand & 5.7 & 0.10 \\
\hline & & LAMELLAE & 89 & 9 & 2 & fine sand & 5.5 & 0.13 \\
\hline \multicolumn{9}{|c|}{ L3 Podzolic brown-rusty soil (humic, covered) (PSC 2019); Dystric Brunic ARENOSOL (Humic, Areninovic) (WRB 2015) } \\
\hline $\mathrm{Ol}$ & $4-0$ & - & n.a. & n.a. & n.a. & n.a. & 4.8 & 37.26 \\
\hline A & $0-8$ & - & n.a. & n.a. & n.a. & n.a. & 4.1 & 2.82 \\
\hline $\mathrm{E}$ & $8-16$ & - & 95 & 5 & 0 & fine sand & 4.3 & 0.81 \\
\hline $\mathrm{BC}$ & $16-40$ & - & 96 & 2 & 2 & fine sand & 4.6 & 0.73 \\
\hline $\mathrm{Ab}$ & $40-60$ & - & 89 & 9 & 2 & fine sand & 4.6 & 1.96 \\
\hline $\mathrm{AE}$ & $60-75$ & - & 86 & 12 & 2 & loamy fine sand & 5.9 & 2.09 \\
\hline Bvb & 75-110 & - & 87 & 12 & 1 & fine sand & 6.6 & 0.70 \\
\hline \multirow[t]{2}{*}{$\mathrm{C} 1$} & $110-133$ & INTERLAMELLAE & 97 & 3 & 0 & fine sand & 6.6 & 0.30 \\
\hline & & LAMELLAE & 88 & 11 & 1 & fine sand & 6.7 & 0.43 \\
\hline \multirow[t]{2}{*}{$\mathrm{C} 2$} & 133-(200) & INTERLAMELLAE & 97 & 3 & 0 & fine sand & 6.6 & 0.22 \\
\hline & & LAMELLAE & 86 & 12 & 2 & loamy fine sand & 6.7 & 0.31 \\
\hline
\end{tabular}

n.a. - not analyzed 

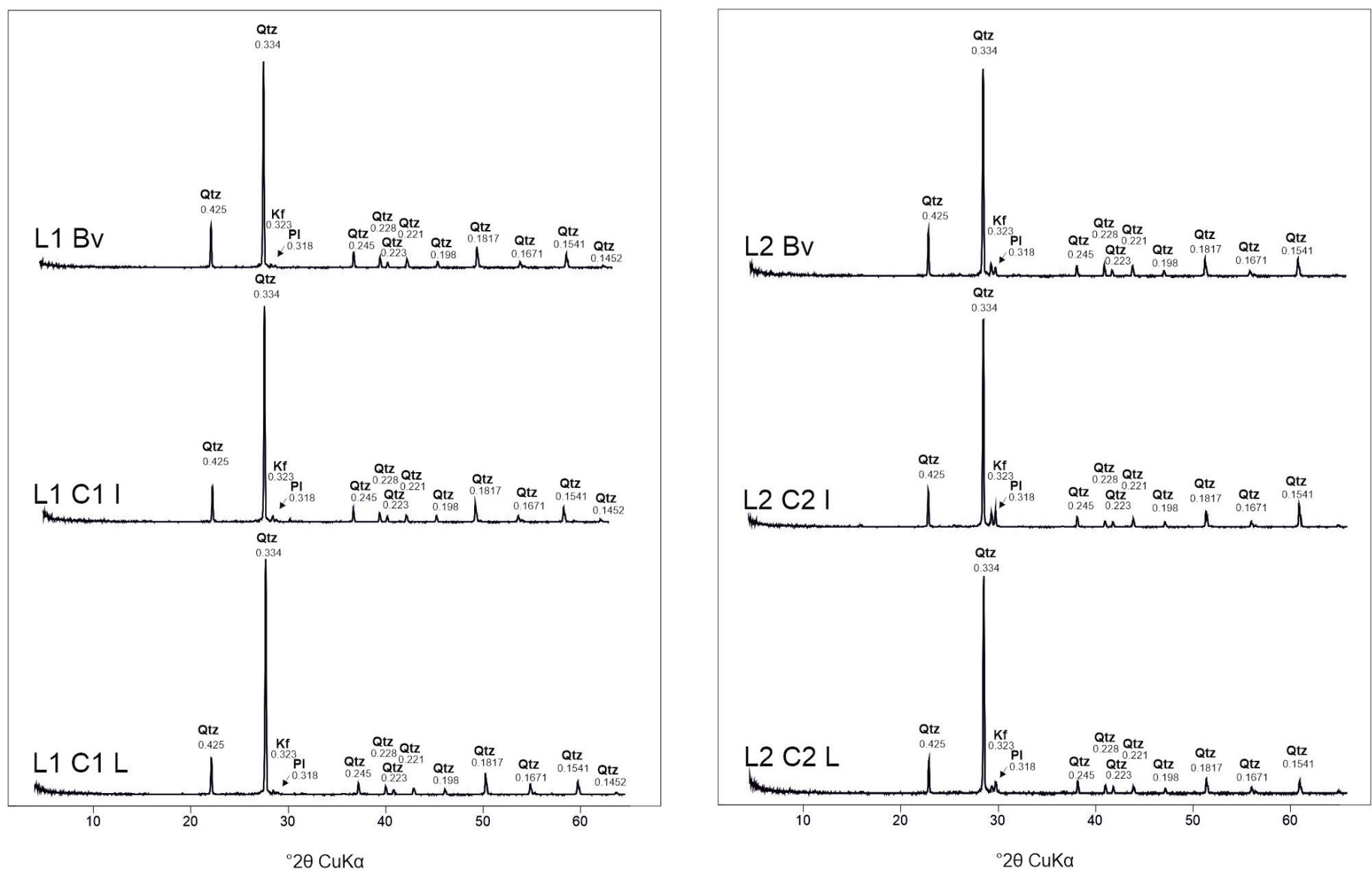

Fig. 2. XRD patterns of bulk soil samples (<2 mm) obtained from siderik horizons (Bv) and parent material (C) of studied soils: L1 - profile L1, L2 - profile L2, I - interlamellae, L - lamellae, Qtz - quartz, Kf - K-feldspar, Pl - plagioclase

content (up to 4 times higher) and clay content (2 times higher) than interlamellae. The studied rusty soils, lamellae, and interlamellae had a similar mineral composition (Fig. 2) with a predominance of quartz, K-feldspar, and plagioclase.

All the studied soils were mostly acidic ( $\mathrm{pH}$ values ranged from 4.1 to 5.9). A relatively higher $\mathrm{pH}$ values were determined in buried L3 profile ( $\mathrm{pH}$ values ranged from 6.6 to 6.7) (Table 4). Generally, the studied lamellae had a higher $\mathrm{pH}$ than interlamellae, with the exception of BC horizons in the L1 profile and the $\mathrm{C} 2$ horizon in the $\mathrm{L} 2$ profile. TOC content in the studied organic soil horizons (litter) ranged from $23.25 \%$ to $37.26 \%$ (Table 4 ), while in A horizons - from $1.07 \%$ to $2.82 \%$. A relatively high content of TOC was determined in the buried siderik horizon $(0.70 \%)$ in the L3 profile, while in the L1 and L2 profiles it was $0.19 \%$ and $0.20 \%$, respectively. TOC content in the studied lamellae was slightly higher (ranging from $0.08 \%$ to $0.43 \%$ ) than in the studied interlamellae (ranging from $0.08 \%$ to $0.30 \%$ ) (Table 4 ).

The total content of iron $\left(\mathrm{Fe}_{\mathrm{t}}\right)$ was slightly higher in the L1 profile than the L2 and L3 profiles and ranged from 4.70 to 16.72 $\mathrm{g} \mathrm{kg}^{-1}$ (Table 5). The $\mathrm{Fe}_{\mathrm{t}}$ content in the L2 and L3 profiles was similar and ranged from 5.04 to $7.34 \mathrm{~g} \mathrm{~kg}^{-1}$ and from 4.05 to 6.55 $\mathrm{g} \mathrm{kg}^{-1}$, respectively. The content of $\mathrm{Fe}_{\mathrm{t}}$ was higher in the lamellae than that in interlamellae (Table 5). The distribution of non-silicate forms of iron (CBD-extractable iron and oxalate-extractable iron) in the soil profile indicated strong enrichment in lamellae in relation to interlamellae. Similarly, the Bs horizon in the L2 profile was enriched in both $\mathrm{Fe}_{\mathrm{d}}$ and $\mathrm{Fe}_{\mathrm{o}}$ (3.00 and $1.41 \mathrm{~g} \mathrm{~kg}^{-1}$, respectively). The content of non-silicate forms of iron in siderik $\mathrm{Bv}$ horizons in the L1 and L2 profiles was similar and ranged from 1.68 to $1.92 \mathrm{~g} \mathrm{~kg}^{-1}$ for $\mathrm{Fe}_{\mathrm{d}}$ and from 0.42 to $0.76 \mathrm{~g} \mathrm{~kg}^{-1}$ for $\mathrm{Fe}_{\mathrm{o}}$, respectively. In turn, the content of $\mathrm{Fe}_{\mathrm{d}}$ and $\mathrm{Fe}_{0}$ in the siderik $\mathrm{Bv}$ horizon in the L3 profile was lower: 0.68 and $0.67 \mathrm{~g} \mathrm{~kg}^{-1}$, respectively (Table 5).

The lowest values of the $\mathrm{Fe}_{\mathrm{o}} / \mathrm{Fe}_{\mathrm{d}}$ index (iron activity ratio) were calculated for the L1 profile, while for the L2 and L3 profiles it was up to three times higher. The degree of weathering ratio $\left(\mathrm{Fe}_{\mathrm{d}} / \mathrm{Fe}_{\mathrm{t}}\right)$, however, was higher for the L1 and L2 profiles than the L3 profile. Both index values $\left(\mathrm{Fe}_{\mathrm{o}} / \mathrm{Fe}_{\mathrm{d}}\right.$ and $\left.\mathrm{Fe}_{\mathrm{d}} / \mathrm{Fe}_{\mathrm{t}}\right)$ suggested no major differences between lamellae and interlamellae, with the exception of the L3 profile, where values were higher for lamellae than interlamellae (Table 5).

The content of $\mathrm{Al}_{\circ}$ was moderately high (Table 5) and ranged from 0.62 to $0.82 \mathrm{~g} \mathrm{~kg}^{-1}$ in profile L1, from 0.28 to 1.44 $\mathrm{g} \mathrm{kg}^{-1}$ in profile L2, and from 0.39 to $1.40 \mathrm{~g} \mathrm{~kg}^{-1}$ in profile L3. The of $\mathrm{Al}_{0}+1 / 2 \mathrm{Fe}_{\mathrm{o}}$ index was relatively high for the Bs horizon in the L2 profile (2.14) and Bv horizons in all the studied soils (ranging from 0.97 to 1.44), and was also higher for lamellae (ranging from 0.93 to 1.31) than interlamellae (ranging from 0.49 to 0.94$)$. 
Table 5

Content of total and non-silicate forms of iron, amorphous aluminum, and indices of soil development in the selected horizons of the studied soils

\begin{tabular}{|c|c|c|c|c|c|c|c|c|c|}
\hline \multirow[t]{2}{*}{ Horizon } & Depth & \multirow[t]{2}{*}{ Lamellae/ interlamellae } & $\mathrm{Fe}_{t}$ & $\mathrm{Fe}_{\mathrm{d}}$ & $\mathrm{Fe}_{\mathrm{o}}$ & $\mathrm{Al}_{\mathrm{o}}$ & \multirow[t]{2}{*}{$\mathrm{Fe}_{\mathrm{o}} / \mathrm{Fe}_{\mathrm{d}}$} & \multirow[t]{2}{*}{$\mathrm{Fe}_{\mathrm{d}} / \mathrm{Fe}_{\mathrm{t}}$} & \multirow[t]{2}{*}{$\mathrm{Al}_{\mathrm{o}}+1 / 2 \mathrm{Fe}_{\mathrm{o}}$} \\
\hline & $\mathrm{cm}$ & & \multicolumn{4}{|l|}{$\mathrm{g} \mathrm{kg}^{-1}$} & & & \\
\hline \multicolumn{10}{|c|}{ L1 Brown-rusty soil (proto-lamellar) (PSC 2019); Dystric Lamellic Brunic ARENOSOL (Ochric) (WRB 2015) } \\
\hline A & $0-14$ & - & 10.71 & 2.95 & 0.77 & 0.82 & 0.26 & 0.28 & 1.21 \\
\hline $\mathrm{Bv}$ & $14-40$ & - & 8.59 & 1.68 & 0.42 & 0.79 & 0.25 & 0.20 & 1.00 \\
\hline \multirow[t]{2}{*}{ BC2 } & $60-95$ & INTERLAMELLAE & 5.91 & 1.23 & 0.32 & 0.62 & 0.26 & 0.21 & 0.78 \\
\hline & & LAMELLAE & 7.62 & 2.32 & 0.52 & 0.68 & 0.22 & 0.30 & 0.94 \\
\hline \multirow[t]{2}{*}{ C3 } & $160-(200)$ & INTERLAMELLAE & 5.61 & 1.53 & 0.35 & 0.76 & 0.23 & 0.27 & 0.94 \\
\hline & & LAMELLAE & 16.72 & 4.18 & 0.99 & 0.81 & 0.24 & 0.25 & 1.31 \\
\hline
\end{tabular}

L2 Podzolic brown-rusty soil (proto-lamellar) (PSC 2019); Dystric Lamellic Brunic ARENOSOL (Ochric, Protospodic) (WRB 2015)

\begin{tabular}{|c|c|c|c|c|c|c|c|c|c|}
\hline A & $10-20$ & - & 6.43 & 1.50 & 0.79 & 0.45 & 0.53 & 0.23 & 0.85 \\
\hline $\mathrm{E}$ & $20-25$ & - & 6.29 & 2.06 & 0.81 & 0.69 & 0.40 & 0.33 & 1.09 \\
\hline Bs & $25-35$ & - & 5.60 & 3.00 & 1.41 & 1.44 & 0.47 & 0.54 & 2.14 \\
\hline $\mathrm{Bv}$ & $35-60$ & - & 5.95 & 1.92 & 0.76 & 1.06 & 0.40 & 0.32 & 1.44 \\
\hline $\mathrm{BC}$ & $60-85$ & - & 5.88 & 1.81 & 0.61 & 0.54 & 0.34 & 0.31 & 0.85 \\
\hline \multirow[t]{2}{*}{$\mathrm{C} 2$} & 130-(190) & INTERLAMELLAE & 5.04 & 2.23 & 0.71 & 0.28 & 0.32 & 0.44 & 0.64 \\
\hline & & LAMELLAE & 7.34 & 4.49 & 1.51 & 0.45 & 0.34 & 0.61 & 1.21 \\
\hline \multicolumn{10}{|c|}{ L3 Podzolic brown-rusty soil (humic, covered) (PSC 2019); Dystric Brunic ARENOSOL (Humic, Areninovic) (WRB 2015) } \\
\hline $\mathrm{Ab}$ & $40-60$ & - & 6.27 & 1.58 & 0.66 & 1.27 & 0.42 & 0.25 & 1.60 \\
\hline $\mathrm{AE}$ & $60-75$ & - & 5.87 & 0.68 & 0.67 & 1.40 & 0.99 & 0.12 & 1.74 \\
\hline Bvb & 75-110 & - & 5.31 & 0.68 & 0.39 & 0.77 & 0.57 & 0.13 & 0.97 \\
\hline \multirow[t]{2}{*}{$\mathrm{C} 1$} & 110-133 & INTERLAMELLAE & 4.18 & 0.40 & 0.20 & 0.39 & 0.50 & 0.10 & 0.49 \\
\hline & & LAMELLAE & 5.29 & 0.92 & 0.75 & 0.55 & 0.82 & 0.17 & 0.93 \\
\hline
\end{tabular}

\subsection{Micromorphological properties}

Micromorphological studies of the Bv and Bs horizons show a dominance of more or less rounded quartz grains in soil material forming a mostly subangular blocky microstructure.
However, in some places siderik Bv horizons exhibited some features of single-grain microstructure. The Bv and Bs horizons were characterized by complex packing voids and channel microporosity. In the groundmass a small quantity of mica, feldspar, and chlorite was noted. Remains of poorly decomposed
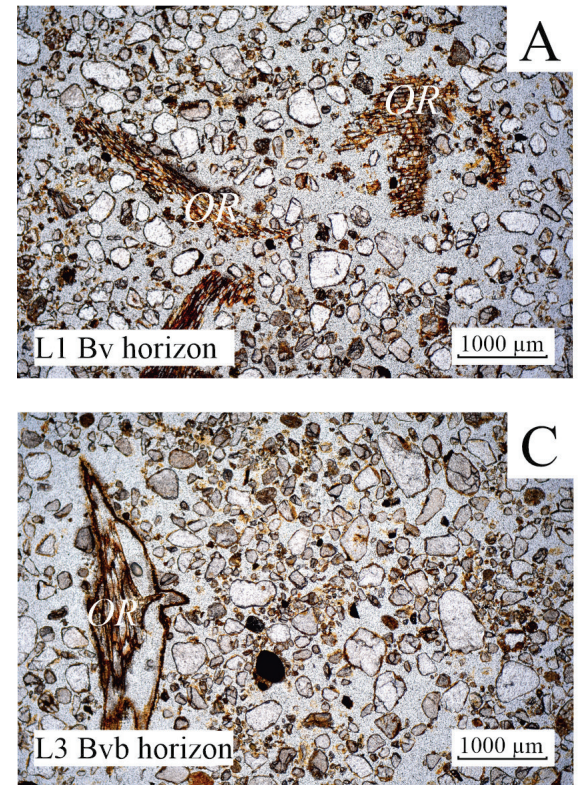
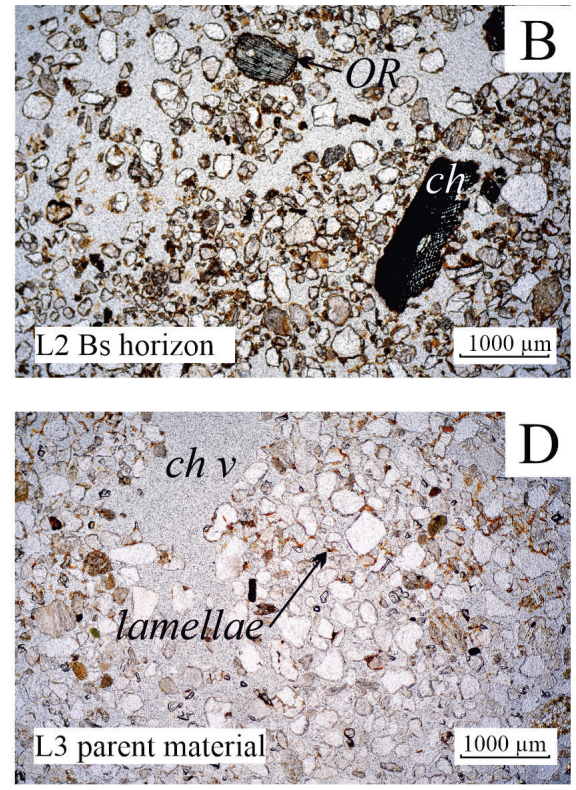

Fig. 3. Organic materials and evidence of high biological activity in studied soils. (A) Organic remnants (OR) with visible tissue structure in siderik Bv horizon in L1 profile; (B) Organic remnants (OR) and charcoal (ch) in illuvial Bs horizon in L2 profile; (C) Organic remnant (OR) in Bvb horizon in L3 profile; (D) channel pore (ch v) crossing lamellae in parent material in L3 profile 
roots (Fig. 3A, C) and charcoals (Fig. 3B) were very common in coarse material of the studied soils. The fine fraction in the $\mathrm{BV}$ and Bs horizons was dominated by iron compounds mostly in the form of coatings and zones of enrichment with a concentration of amorphous organic matter (Fig. 4). The presence of single illuvial clay coatings and a few Fe-Mn nodules were also observed.

Lamellae in the $\mathrm{BC} 1$ horizon in the L1 profile were characterized by the occurrence of fine quartz grains and weaklydeveloped clay-iron coatings on quartz grains (Fig. 5). Below,
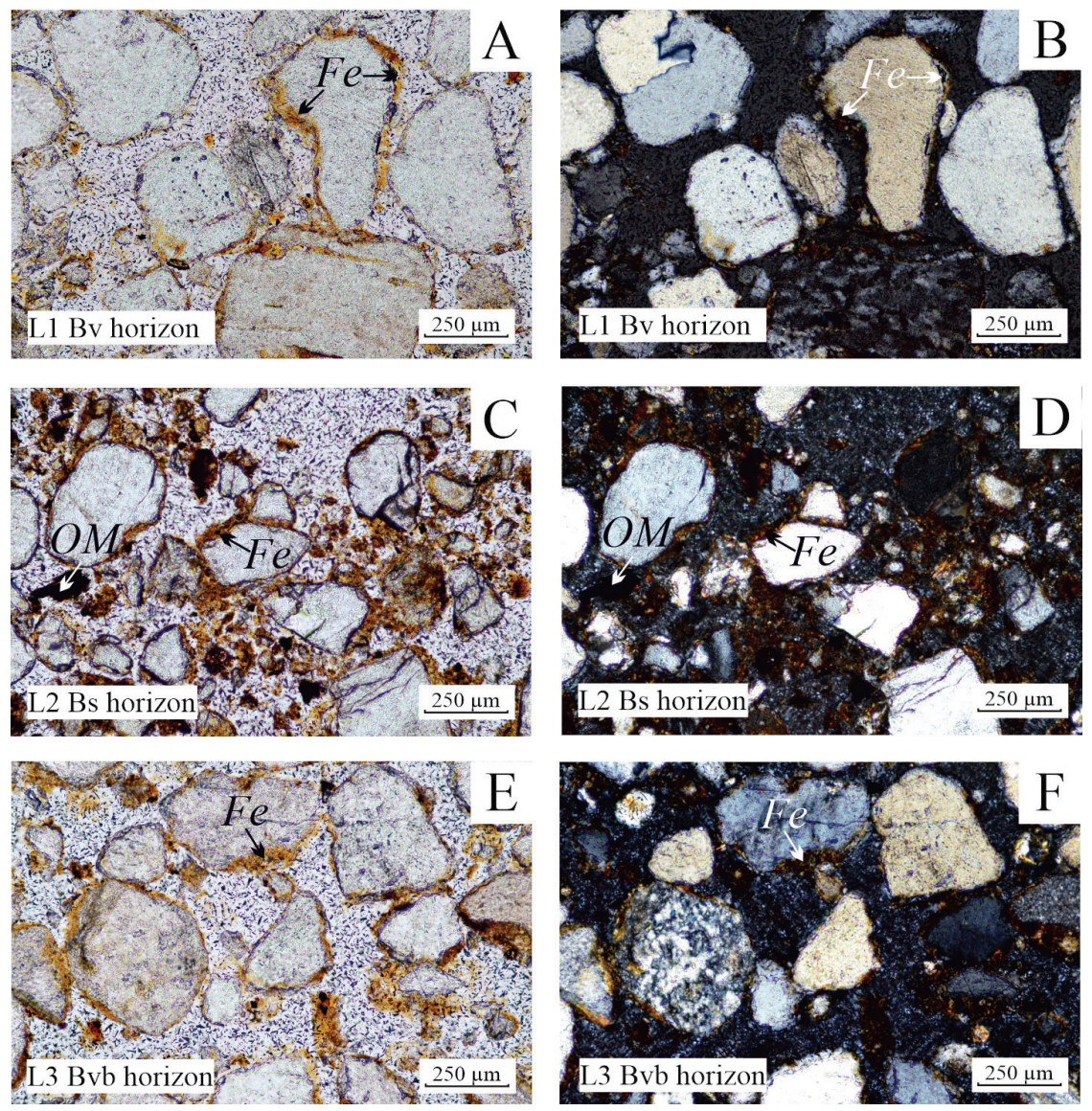

Fig. 4. Micromorphological features of siderik $\mathrm{Bv}$ horizons and illuvial Bs horizon. (A, B) Bv horizon in L1 profile with iron coatings (Fe) on mineral grains; (C, D) Illuvial Bs horizon in L2 profile with cracked iron coatings (Fe) on mineral grains and amorphous organic matter (OM); (E, F) Bvb horizon in L3 profile with iron coatings (Fe) on mineral grains. Plane-polarized light (PPL) (A, C, E) and cross-polarized light (XPL) (B, D, F)
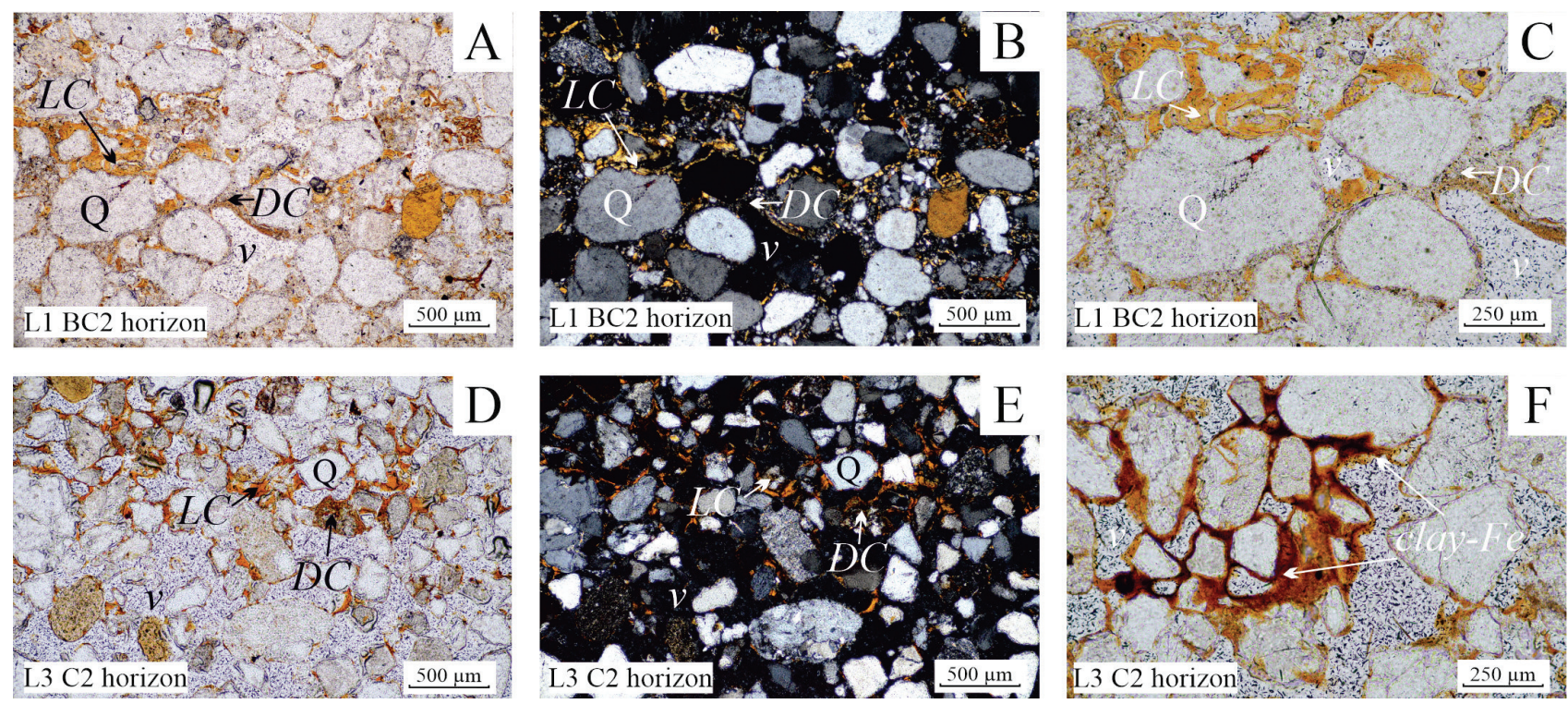

Fig. 5. Soil lamellae coatings and bridges in selected horizons. (A, B, C) Lamellae in BC2 horizon in L1 profile with microlaminated clay coatings (LC - limpid clay coatings, DC - dusty-clay coatings) and infillings occurring on and between quartz grains (Q); (D, E) Lamellae in C2 horizon in L3 profile with microlaminated clay coatings (LC - limpid clay coatings, DC - dusty-clay coatings) and infillings; (F) clay-iron coatings (clay-Fe) occurring on and between quartz grains (Q); v - voids. Plane-polarized light (PPL) (A, C, D, F) and cross-polarized light (XPL) (B, E) 

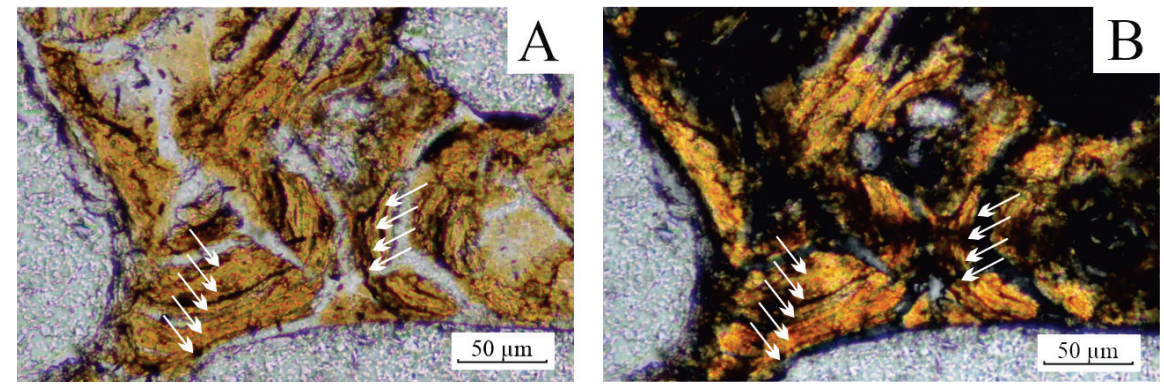

B
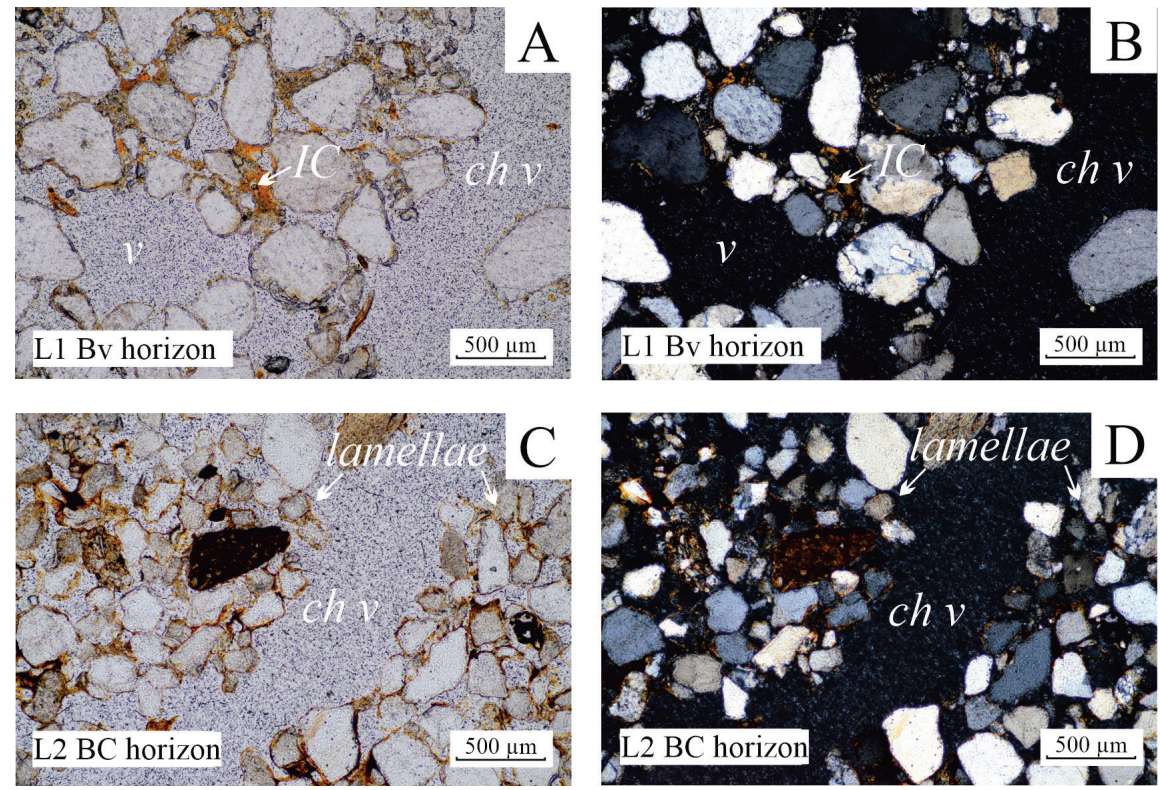

Fig. 6. Lamellae in BC2 horizon in L1 profile with microlaminated clay coatings and infillings on and between quartz grains (white arrows). Plane polarized light (PPL) (A) and cross-polarized light (XPL) (B)
Fig. 7. Fragments of degraded soil lamellae with illuvial clay (IC) on mineral grains in Bv horizon in L1 profile (A, B) and lamellae divided by channel void (v) in BC horizon in L2 profile (C, D) in lamellae in the BC2 horizon, well-formed, layered, yellowish clay coatings characteristic of illuviation prevailed. In turn, both dusty and dispersed iron-clay coatings in lamellae were observed in the parent material. Lamellae noted in the $\mathrm{C} 2$ horizon in the L3 profile consisted of various types of clay-iron coatings and bridges linking quartz grains. More compacted, wellformed, layered, yellowish-red clay-iron coatings predominated in the abovementioned horizon (Fig. 45). However, the presence of more dispersed limpid and dusty clay coatings was also observed.

The presence of former soil lamellae in the siderik Bv horizon was noted in the L1 profile (Fig. 7). Fragmented parts of soil lamellae occurred as a form of elongated, discontinuous zones of clay-iron coatings on mineral grains (Fig. 7). In turn, clear fragments of soil lamellae were not observed in the siderik horizon in the L3 profile.

\section{Discussion}

\subsection{Rusty soils (Brunic Arenosols) in southeastern Poland}

All the studied rusty soils (Brunic Arenosols) had developed from sandy parent material of glaciofluvial origin. The examined rusty soils (Brunic Arenosols) slightly differ in terms of soil-forming processes, which is likely related to dominant veg- etation type (Table 1, Fig. 1). However, the physical and chemical properties of the studied rusty soils (Brunic Arenosols) are similar to those of rusty soils (Brunic Arenosols) found in other areas in Poland (Kowalkowski, 1977; Bednarek, 1991; Janowska, 1994; 2001; Manikowska and Bednarek, 1994; Konecka-Betley and Janowska, 1996; Prusinkiewicz et al., 1998; Jankowski, 2014; Bryk, 2016). One of the features of such soils is the presence of a diagnostic siderik Bv horizon, which occurs in all pedons. Accumulation of organo-mineral complexes as coatings on quartz grains is typical of Bv horizons (Bednarek, 1991). Such coatings were found in Bv horizon in the L1 profile which confirmed the formation of a siderik Bv horizon. Such a feature is typical of rusty soils (Brunic Arenosols), and together with other features, such as well-developed soil structure and loamy fine sand texture (Tables 2 and 3), allows to classify this pedon as a brownrusty soil (proto-lamellar) (Kabała et al., 2019; Polish Soil Classification, 2019) and Dystric Lamellic Brunic Arenosol (Ochric) (IUSS Working Group WRB, 2015). Micromorphological features of the Bv horizon in the L1 profile suggest the presence of enrichment zones of oriented clay accompanying iron oxides (Fig. 4A, B). Moreover, the L1 profile was characterized by the lack of depletion of iron and aluminum compounds in the A horizon in comparison to the siderik Bv horizon (Table 5), which is also a characteristic feature of rusty soils (Brunic Arenosols), and has been described in other studies (Konecka-Betley, 1968; Bednarek, 1991; Martyn and Niemczuk, 2011; Jankowski, 2014). 
In turn, the L2 and L3 profiles exhibit weak features of podzolization reflected by the occurrence of weakly developed eluvial E or transition AE horizons, and in the L2 profile the occurrence of an illuvial Bs horizon. However, the micromorphological features of the Bs and Bv horizons found in the studied soils were very similar in terms of the type of most of coatings on mineral grains, but in the Bv horizon the coatings were continuous, nonlaminated, more dusty, featuring a ragged edges (Fig. 4D, E). The coatings were also lighter in color than those noted in the Bs horizon. These coatings are characteristic for $\mathrm{BV}$ horizons (Hirsch et al., 2019). In turn, some of the iron coatings found in the Bs horizon were cracked and consisted of darker organo-mineral material (Fig. 4 C, D), which is a characteristic feature of illuvial Bs horizons (De Coninck et al., 1974; Buurman et al., 2005; Wilson and Righi, 2010). As described by many authors (Kuźnicki and Skłodowski, 1974; Kowalkowski, 1977; Janowska, 1994; Manikowska and Bednarek, 1994; Kowalkowski, 1998; Konecka-Betley, 2001; Kabała, 2005; Jankowski, 2014), podzolization in rusty soils (Brunic Arenosols) is a common phenomenon related to the effects of acidifying vegetation (mostly non-native Scots pine) and favorable, sandy parent material. In both study sites (L2 and L3) Scots pine was one of the dominant species in mixed forests. Additionally, in the L3 profile the eluvial horizon had developed not only in buried soil, but also in overlying material at a depth of $8 \mathrm{~cm}$, which may show a strong impact of acidifying vegetation on the podzolization process in rusty soils.

Profile distribution of non-silicate forms of iron and aluminum also indicates a podzolization. In the L2 profile the content of non-silicate forms of iron and aluminum indicates the eluviation of the most mobile forms of $\mathrm{Fe}$ and $\mathrm{Al}$ from the eluvial horizon (Table 5). In turn, in the L3 profile, the highest content of $\mathrm{Al}_{\mathrm{o}}$ and $\mathrm{Fe}_{\mathrm{o}}$ was noted in buried $\mathrm{A}$ and $\mathrm{AE}$ horizons, which also shows its accumulation in the uppermost horizons of the former soil. Similar observations were conducted by Manikowska and Bednarek (1994) in the A and Bv horizons in fossil rusty soil. Such accumulation may also indicate a "depodzolization effect", as described by Barrett and Schaetzl (1998) and Jankowski (2014) in other podzolized, rusty soils.

One of the features distinguishing the investigated rusty soils (Brunic Arenosols) from those described by other authors is the presence of lamellae, which serves as some evidence of at least a partial displacement of iron, aluminum, and the clay fraction in the profiles of the rusty soils (Brunic Arenosols).

\subsection{Soil lamellae in the studied soils}

In all the studied rusty soils (Brunic Arenosols), soil lamellae were well-developed in the BC horizon and parent material (Table 3). According to the literature (Bullock and Mackney, 1970; Boubaid et al., 1992; Kilibarda et al., 2008; Muhs, 2017), such wellexpressed lamellae found at greater depths indicate petrogenic origin. However, our investigation suggests a pedo-petrogenic origin of lamellae. Field observations and micromorphological studies have confirmed that soil lamellae studied herein are not fully related to stratified layers of sand in parent material and BC horizons and often cross-cut bedding planes. The very wavy and irregular shape (Table 3, Fig. 1) noted in all the studied horizons with lamellae in all the soils additionally confirmed that the origin of the examined lamellae is pedo-petrogenic.

Moreover, some data indicate that deposition of sandy material in fluvial environment played an important role in accumulation of illuvial clay, because features such sorting and packing of mineral grains and pore discontinuities have an impact on redistribution and accumulation of clay particles (Boubaid et al., 1992; Schaetzl, 1992; Rawling, 2000). Micromorphological data (Figs. 5, 6 and 7) indicate the domination of illuviation (treated as pedogenic process) on lamellae origin. One of the most important evidence of the impact of pedogenic processes on lamellae formation in the examined rusty soils (Brunic Arenosols) is the presence of well-developed, illuvial coatings within lamellae in all the studied horizons (Fig. 5). The enrichment of illuvial clay may be the result of the translocation of clay particles in permeable sandy material (Kühn et al., 2010), probably before rusty soil formation (Bond, 1986; Schaetzl, 1992), as shown by micromorphological observations that indicate the presence of oriented clay coatings on mineral grains, even in parent material (Fig. 5).

Soil lamellae were also characterized by the presence of iron or clay-iron coatings (Fig. 5F), which are the result of iron redistribution, as described by Miedema et al. (1987) and by Stoops and Marcelino (2018) in consecutive stages of clay illuviation in lamellae. Thus, the impact of pedogenic processes is important for lamellae origin and transformation (Torrent et al., 1980; Kemp and McIntosh, 1989; Phillips, 2004; Kilibarda et al., 2008; May and Veit, 2009; Jankowski, 2012; Phillips et al., 2015; Lisa et al. 2019).

Moreover, the morphology of all the studied rusty soils (Brunic Arenosols) (Table 2, Fig. 1) and observed lamellae disappearance in siderik Bv horizons, improvement of their expression in transitional BC horizons, as well as presence of lamellae in parent material (Table 3) indicate that lamellae formed prior to siderik Bv horizon.

Our research results indicate that lamellae mostly occur in transitional BC horizons and in the parent material and are usually absent (or occur only fragmentarily) in the siderik Bv horizon. In other studies describing rusty soils (Brunic Arenosols), lamellae were also absent in siderik Bv horizons (Jankowski, 2012; Hirsch et al., 2019; Kruczkowska et al., 2020). Such a result may indicate the impact of processes occurring in the upper part of the solum on lamellae transformation and their degradation. One of the possible causes of lamellae fragmentation may be high biological activity reflected by the presence of many roots and some burrows in the soil (Table 2) as well as channel microporosity (Figs. 3 and 7). High biological activity may lead to the bioturbation of soil material, which may cause an interruption in lamellae. Similar observations were made by Johnson et al. (2008) on sandy soils along Indian Creek in central Iowa, USA, and by Holliday and Rawling (2006) in dune fields on the Southern High Plains, USA. The above authors described a high impact of bioturbation in the active biomantle zone on the periodic disruption of lamellae. The siderik Bv horizon in the L1 profile is an example of such processes. Although in macroscopic observations soil lamellae were not visible in the Bv horizon, micromorphological studies indicated the presence of fragments 
of former lamellae (papules) with well-developed, oriented clay featuring visible, small-scale lamination (same as in well-developed and preserved lamellae in BC horizons) on coarse grains in the Bv horizon (Fig. 6). Similar observations of lamellae fragments were described by Robinson and Rich (1960) in the upper part of the soil in the form of small, clay-enriched minerals, elongated nodules, which may suggest the previous presence of lamellae that experienced degradation by soil processes. This is also an another evidence of formation of lamellae prior to siderik horizon formation. These lamellae were degraded due to the development of siderik Bv horizon and an intense biological activity strictly related to Bv horizons. The observed channels that break and divide the lamellae as well as the many cracks and pores found within fragmented lamellae material together with organic remnants indicate an impact of bioturbation on lamellae degradation (Fig. 7).

In turn, soil lamellae were absent in siderik Bv horizons in the L2 and L3 profiles and even micromorphological studies did not show the presence of lamellae fragments. Lamellae occur fragmentarily in the transitional BC horizon in the L2 profile, which is also the result of the deep degradational impact of bioturbation (Fig. 7). The relatively large number of roots and organic matter residues noted in field observations, as well as presence of burrows (indicating impact of pedofauna), divided lamellae. Such morphological and micromorphological features indicate mainly the impact of biological activity (Kooistra and Pulleman, 2010).

Soil lamellae in transitional BC horizons and the parent material were found to be well-expressed. Lamellae material beside clay and iron-clay coatings consist of fine quartz grains and amorphous organic matter. Observations of lamellae sequences in the studied rusty soils (Brunic Arenosols) showed the highest thickness and more color intensity in the uppermost lamellae in such sequences, and weakening expression with depth. Better developed clay and clay-iron coatings and the higher concentration of these coatings in the upper part of lamellae sequences may indicate an improvement in lamellae expression due to illuviation and accumulation of the finest particles. Similar results have been obtained by other researchers studying lamellae in sandy material (Berg, 1984; Kemp and McIntosh, 1989; Rawling, 2000; Holliday and Rawling, 2006; Johnson et al., 2008). Such improvement of lamellae expression in uppermost part of transitional BC horizons and in parent material occur most likely after formation of siderik Bv horizons.

\section{Conclusions}

1. Well-developed lamellae in the transitional BC horizon and parent material occur in rusty soils (Brunic Arenosols) formed from glaciofluvial sands in southeastern Poland. They exhibit a slightly higher content of silt and clay fractions, and total organic carbon and higher content of nonsilicate iron and aluminum compounds in comparison to interlamellae.

2. Origin of the studied lamellae is pedo-petrogenic. Lamellae were formed as a result of clay illuviation prior to the de- velopment of rusty soil, which was shown by the common occurrence of illuvial clay, iron, and iron-clay coatings on coarse grains.

3. Lamellae occur only fragmentarily in the siderik Bv horizon due to their biogenic degradation in the biomantle zone and this was evidenced by micromorphological analysis. In transitional $\mathrm{BC}$ horizons and in parent material expression of soil lamellae were improved due to illuviation and accumulation of clay and iron compounds.

\section{Acknowledgments}

The herein discussed research was financed by the National Science Centre, Poland (Grant No. 2018/29/N/ST10/00398). The authors would like to thank editors and anonymous reviewers for their helpful suggestions and constructive comments that significantly increased the scientific quality of the paper. Language editing was done by Greg Zębik.

\section{References}

Barrett, L.R., Schaetzl, R.J., 1998. Regressive pedogenesis following a century of deforestation: evidence for depodzolization. Soil Science 163(6), 482-495.

Bednarek, R., 1991. Wiek, geneza i stanowisko systematyczne gleb rdzawych w świetle badan paleopedologicznych w okolicach Osia (Bory Tucholskie). Rozprawy UMK, Toruń.

Bednarek, R., Kamiński, D., Markiewicz, M., Chrzanowski, W., Zbyszewska, K., 2010. Transformations of soils and forest communities in the area of early medieval strongholds (examples from Chełmno Land). Polish Journal of Soil Science 43(1), 93-101.

Berg, R.C., 1984. The origin and early genesis of clay bands in youthful sandy soils along Lake Michigan, USA. Geoderma 32, 42-62. https:// doi.org/10.1016/0016-7061(84)90076-4

Bockheim, J.G., Hartemink, A.E., 2013. Classification and distribution of soils with lamellae in the USA. Geoderma 206, 92-100. https://doi. org/10.1016/j.geoderma.2013.04.014

Bokwa, A., Hajto, M., Walawender, J., Szymanowski, M., 2015. Influence of diversified relief on the urban heat island in the city of Kraków, Poland. Theoretical and Applied Climatology 122, 365-382. https://doi. org/10.1007/s00704-015-1577-9

Bond, W.J., 1986. Illuvial band formation in a laboratory column of sand. Soil Science Society of America Journal 50, 265-267. https://doi. org/10.2136/sssaj1986.03615995005000010054x

Boubaid, R., Nater, E.A., Barak, P., 1992. Measurement of pore size distribution in a lamellar Bt horizon using epifluorescence microscopy and image analysis. Geoderma 53, 309-328. https://doi.org/10.1016/00167061(92)90061-B

Bryant, I.D., 1982. Loess deposits in Lower Adventdalen, Spitsbergen. Polar Research 1982(2), 93-103. https://doi.org/10.3402/polar.v1982i2.7006

Bryk, M., 2016. Macrostructure of diagnostic B horizons relative to underlying BC and C horizons in Podzols, Luvisol, Cambisol, and Arenosol evaluated by image analysis. Geoderma 263, 86-103. https://doi. org/10.1016/j.geoderma.2015.09.014

Bullock, P., Mackney, D., 1970. Micromorphology of strata in the Boyn Hill Terrace deposits, Buckinghamshire. [In:] Osmond, D.A., Bullock, P. (Eds.)., Micromorphological Techniques and Applications. Agricultural Research Council, Soil Survey, Technical Monograph No. 2 pp. 97-107.

Buurman, P., Van Bergen, P.F., Jongmans, A.G., Meijer, E.L., Duran, B., Van Lagen, B., 2005. Spatial and temporal variation in podzol organic 
matter studied by pyrolysis-gas chromatography/mass spectrometry and micromorphology. European Journal of Soil Science 56, 253-270. https://doi.org/10.1111/j.1365-2389.2004.00662.x

Chojnicki, J., Piotrowska, J., 2010. Właściwości morfologiczne i fizykochemiczne gleb Rezerwatu "Rybitew” Kampinoskiego Parku Narodowego (Morphological and physical-chemical properties of the "Rybitew" Reservation soils in the Kampinos National Park). Roczniki Gleboznawcze - Soil Science Annual 61(2), 21-28.

Coen, G.M., Pawluk, S., Odynsky, W., 1966. The origin of bands in sandy soils of the stony plain area. Canadian Journal of Soil Science 46, 245-254. https://doi.org/10.4141/cjss66-039

De Coninck, F., Righi, D., Maucorps, J., Robin, A.M., 1974. Origin and micromorphological nomenclature of organic matter in sandy Spodosols. [In:] Rutherford, G.K. (ed.), Soil Microscopy. The Limestone Press, Kingston, Ontario, 263-280.

Dijkerman, J.C., Cline, M.G., Olson, G.W., 1967. Properties and Genesis of textural subsoil lamellae. Soil Science 104, 7-16.

FitzPatrick, E.A., 1984. The micromorphology of soils. Springer, Dordrecht.

Furquim, S.A.C., Coltrinari, L., Dias Ferreira, R.P., Castro, S.S., Pugliese, G.R., 2013. Lamellae formation processes in tropical soils in southeastern Brazil. Catena 107, 15-25. https://doi.org/10.1016/j.catena.2013.03.005

Gile, L.H., 1979. Holocene soils in eolian sediments of Bailey County, Texas. Soil Science Society of America Journal 43, 994-1003. https://doi. org/10.2136/sssaj1979.03615995004300050037x

Gradziński, M., Gradziński, R., 2015. Geology. [In:] Baścik M., Degórska B., (Eds.). Środowisko przyrodnicze Krakowa: zasoby, ochrona, kształtowanie. 2 zm. i uzup. Kraków: Instytut Geografii i Gospodarki Przestrzennej Uniwersytetu Jagiellońskiego, 23-32. (in Polish).

Hirsch, F., Bonhage, A., Bauriegel, A., Schneider, A., Raab, T., Raab, A., Gypser, S., 2019. The occurrence, soil parameters and genesis of rubified soils ('Fuchserden') of northeastern Germany. Catena 175, 77-92. https://doi.org/10.1016/j.catena.2018.11.039

Holliday, V.C., Rawling, III J.E., 2006. Soil-geomorphic relations of lamellae in eolian sand on the High Plains of Texas and New Mexico. Geoderma 131, 154-180. https://doi.org/10.1016/j.geoderma.2005.03.019

IUSS Working Group WRB, 2015. World Reference Base for Soil Resources 2014, update 2015: International soil classification system for naming soils and creating legends for soil maps. World Soil Resources Reports, 106, FAO, Rome.

Jahn, R., Blume, H.-P., Asio, V.B., Spaargaren, O., Schad, P., 2006. Guidelines for soil description. $4^{\text {th }}$ ed., FAO, Rome, Italy.

Jankowski, M., 2012. Lateglacial soil paleocatena in inland-dune area of the Toruń Basin, Northern Poland. Quaternary International 265, 116-125. https://doi.org/10.1016/j.quaint.2012.02.006

Jankowski, M., Przewoźna, B., Bednarek, R., 2011. Topographical inversion of sandy soils due to local conditions in Northern Poland. Geomorphology 135, 277-283. https://10.1016/j.geomorph.2011.02.005

Jankowski, M., 2014. Bielicowanie jako wtórny process w glebach rdzawych Brodnickiego Parku Krajobrazowego. [In:] Świtoniak, M., Jankowski, M., Bednarek, R., (Eds.). Antropogeniczne przekształcenia pokrywy glebowej Brodnickiego Parku Krajobrazowego. Toruń, 9-24. (in Polish)

Janowska, E., 1994. Preliminary studies on the sideric horizon of rusty soils with the use of microchemical X-ray analysis. Roczniki Gleboznawcze - Soil Science Annual 44, 41-53.

Janowska, E., 2001. Geneza i właściwości gleb rdzawych na obszarze zlodowacenia środkowopolskiego, Rozprawa habilitacyjna, Wydawnictwo Fundacja Rozwój SGGW, Warszawa.

Johnson, D.L., Johnson, D.N., Benn, D.W., Bettis, III E.A., 2008. Deciphering complex soil/site formation in sands. Geomorphology 101, 484-496. https://doi.org/10.1016/j.geomorph.2007.04.033

Kabała C., 2005. Geneza i właściwości i występowanie gleb bielicowych w zróżnicowanych warunkach geologicznych Dolnego Śląska. Zeszyty Naukowe AR we Wrocławiu 519.
Kabała, C., Charzyński, P., Chodorowski, J., Drewnik, M., Glina, B., Greinert, A., ...\& Waroszewski, J., 2019. Polish Soil Classification, 6th edition - principles, classification scheme and correlations. Soil Science Annual 70(2), 71-97.

Kemp, R.A., McIntosh, P.D., 1989. Genesis of a textural banded soil in Southland, New Zealand. Geoderma 45, 65-81. https://doi.org/10.1016/00167061(89)90056-6.

Kilibarda, Z., Argyilan, E., Blockland, J., 2008. Wind deposition of mud aggregates and their role in development of lamellae in the Fair Oaks Dunes, Indiana. Catena 72, 235-247. https://doi.org/10.1016/ j.catena.2007.05.006

Konecka-Betley, K., 1968. Zagadnienie żelaza w procesie glebotwórczym. Roczniki Gleboznawcze - Soil Science Annual 19(1), 51-97. (in Polish with English abstract)

Konecka-Betley, K., 2001. Rekonstrukcja przebiegu procesów pedologicznych w późnym plejstocenie i holocenie w środkowej Polsce. Roczniki Gleboznawcze - Soil Science Annual 52(1/2), 99-118.

Konecka-Betley, K., Janowska, E., 1996. Wiek i pochodzenie osadów a niektóre procesy glebotwórcze. Roczniki Gleboznawcze - Soil Science Annual 47, 113-123.

Kooistra, M.J., Pulleman, M.M., 2010. Features related to faunal activity. [In:] Stoops, G., Marcelino, V., Mees, F. (Eds.), Interpretation of Micromorphological Features of Soils and Regoliths. Elsevier, Amsterdam, 397-418.

Kowalkowski, A., 1977. Wpływ różnej głębokości wody gruntowej na wilgotność i zasobność gleb rdzawych bielicowanych pod drzewostanami sosnowymi. Roczniki Gleboznawcze - Soil Science Annual 28(3/4), 127-135. (in Polish)

Kowalkowski, A., 1998. Holocene rusty and rusty podzolic soils in the tundra and taiga of middle Sweden. Roczniki Gleboznawcze - Soil Science Annual 49, 29-44.

Kowalkowski, A., Degórski, M., 2005. Biogeomorfologiczna odrębność górskich strukturalnych gleb rdzawych bielicowych. Problemy Zagospodarowania Ziem Górskich, PAN 52, 7-16. (in Polish)

Kruczkowska, B., Błaszkiewicz, M., Jonczak, J., Uzarowicz, Ł., Moska, P., Brauer, A., Bonk, A., Słowiński, M., 2020. The Late Glacial pedogenesis interrupted by aeolian activity in Central Poland-Records from the Lake Gościąż catchment. Catena 185, 104286. https://doi.org/10.1016/ j.catena.2019.104286

Kuźnicki, F., Skłodowski, P., 1974. Content of various forms of humus compounds in podzolized rusty soils and podzol, develop from fluvioglcial sands. Roczniki Gleboznawcze - Soil Science Annual 25, 185-196.

Kühn, P., Aguilar, J., Miedema, R., 2010. Textural features and related horizons. [In:] Stoops, G., Marcelino, V., Mees, F. (Eds.), Interpretation of Micromorphological Features of Soils and Regoliths. Elsevier, Amsterdam, 217-250. https://doi.org/10.1016/B978-0-444-63522-8.00014-0

Lisá, L., Bajer, A., Rejšek, K., Vranová, V., Vejrostová, L., Wisniewski, A., Krištuf, P., 2019. Review of illuvial bands origin; What might the presence of dark brown bands in sandy infillings of archaeological features or cultural layers mean? Interdisciplinaria Archaeologica. Natural Sciences in Archaeology 1, 19-28. https://doi.org/10.24916/ iansa.2019.1.2

Manikowska, B., Bednarek, R., 1994. Fossil preboreal soil on the dune sands in central Poland and its significance for the conception of rusty soils (cambic arenosols) genesis. Roczniki Gleboznawcze - Soil Sciene Annual 44, 27-29.

Marciniec, P., Zimnal, Z., 2016. Szczegółowa Mapa Geologiczna Polski w skali 1:50000, arkusz Pilzno. Państwowy Instytut Geologiczny, Warszawa.

Martyn, W., Niemczuk, B., 2011, Zawartość żelaza i glinu w profilach gleb rdzawych różnie użytkowanych, Ochrona Środowiska i Zasobów Naturalnych 48, 287-296. (in Polish)

Marzec, M., Kabała, C., 2008. Gleby rdzawe i brunatne kwaśne wytworzone ze zwietrzelin granitów w Sudetach - Morfologia, właściwości 
i systematyka. Roczniki Gleboznawcze - Soil Science Annual 59(3/4), 206-214.

May, J.H., Veit, H., 2009. Late Quaternary paleosols and their paleoenvironmental significance along the Andean piedmont, Eastern Bolivia. Catena 78, 100-116. https://doi.org/10.1016/j.catena.2009.03.003

Mehra, O.D., Jackson, M.L., 1960. Iron oxide removal from soils and clays by a dithionite-citrate system buffered with sodium bicarbonate. Clays and Clay Minerals 5, 317-327. https://doi.org/10.1016/B978-0-08009235-5.50026-7

Miedema, R., Jongmans, A.G., Brinkman, R., 1987. The micromorphology of a typical catena from Sierra Leone, West Africa. [In:] Fedoroff, N., Bresson, L.M., Courty, M.A. (Eds.), Micromorphologie des Sols, Soil Micromorphology. AFES, Paris, 137-144.

Miles, R.J., Franzmeier, D.P., 1981. A lithochronosequence of soils formed in dune sand. Soil Science Society of America Journal 45, 362-367. https://doi.org/10.2136/sssaj1981.03615995004500020027x

Muhs, D.R., 2017. Evaluation of simple geochemical indicators of aeolian sand provenance: Late Quaternary dune fields of North America revisited. Quaternary Science Reviews 171, 260-296. https://doi. org/10.1016/j.quascirev.2017.07.007

Munsell, C., 1975. Standard Soil Color Charts. Munsell Color Co, Baltimore, MD.

Nelson, D.W., Sommers, L.E., 1996. Total Carbon, Organic Carbon, and Organic Matter. [In:] D.L. Sparks et al. (Eds.) Methods of Soil Analysis. Part 3. Chemical Methods - SSSA Book Series no.5. SSSA and ASA, Madison, WI, USA, 961-1010.

Obear, G.R., Pedersen, M., Kreuser, W.C., 2017. Genesis of clay lamellae in golf course soils of Mississippi, USA. Catena 150, 62-70. https://doi. org/10.1016/j.catena.2016.10.019

Obrębska-Starklowa, B., Hess, M., Olecki, Z., Trepińska, J., Kowanetz, L., 1995. Klimat. [In:] Warszyńska, J., (Ed.), Karpaty. Wydawnictwo UJ, Kraków, 31-47.

Phillips, J.D., 2004. Geogenesis, pedogenesis, and multiple causality in the formation of texture-contrast soils. Catena 58, 275-295. https://doi. org/10.1016/j.catena.2004.04.002

Phillips, D.H., Foss, J.E., Goodyear, A.C., 2015. Micromorphology of lamellae formed in an alluvial soil, Big Pine Tree Archaeological Site, South Carolina. Soil Horizons 47(3), 46-50. https://doi.org/10.2136/ sh2006.3.0046

Polish Soil Classification - Systematyka gleb Polski, 2019. Polskie Towarzystwo Gleboznawcze, Komisja Genezy, Klasyfikacji i Kartografii Gleb. Wydawnictwo Uniwersytetu Przyrodniczego we Wrocławiu, Polskie Towarzystwo Gleboznawcze, Wrocław-Warszawa, 290 pp. (in Polish with English abstract)

Prusinkiewicz, Z., Bednarek, R., Kośko, A., Szmyt, M., 1994. Wiek, właściwości i geneza wstęg iluwialnych w świetle badań paleopedologicznych i archeologicznych (Age, properties and genesis of illuvial bands in the light of paleopedological and archaeological investigations). Roczniki Gleboznawcze - Soil Science Annual 45(1/2), 5-19. (in Polish with English abstract)
Prusinkiewicz, Z., Bednarek, R., Kosko, A., Szmyt, M., 1998. Paleopedological studies of the age and properties of illuvial bands at an archeological site. Quaternary International 51/52, 195-201. https://doi. org/10.1016/S1040-6182(97)00045-1

Rawling, J.E., 3rd., 2000. A review of lamellae. Geomorphology 35, 1-9. https://doi.org/10.1016/S0169-555X(00)00015-5

Robinson, G.H., Rich, C.I., 1960. Characteristic of the multiple yellowishred bands common to certain soils in the south-eastern United States. Soil Science Society of America Proceedings 24, 226-230. https://doi. org/10.2136/sssaj1960.03615995002400030029x

Rutkowski, J., 1993. Szczegółowa Mapa Geologiczna Polski w skali 1:50000, arkusz Kraków. Państwowy Instytut Geologiczny, Warszawa.

Schaetzl, R.J., 1992. Texture, mineralogy and lamellae development in sandy soils in Michigan. Soil Science Society America Journals 56, 1538-1545. https://doi.org/10.2136/sssaj1992.03615995005600050034x

Schaetzl, R.J., 2001. Morphologic evidence of lamellae forming directly 854 from thin, clayey bedding planes in a dune. Geoderma 99, 51-63. https://doi.org/10.1016/S0016-7061(00)00063-X

Schwertmann, U., 1964. Differenzierung der Eisenoxide des Bodens durch Extraktion mit Ammoniumoxalat e Lösung. Zeitschrift für Pflanzenernährung, Düngung, Bodenkunde 105(3), 194-202.

Soil Survey Staff, 1999. Soil Taxonomy: A basic system of soil classification for making and interpreting Soil Surveys. United States Department of Agriculture Handbook 436, 2nd. ed., 869.

Stoops, G., 2003. Guidelines for analysis and description of soil and regolith thin section, Soil Science Society America, INC, Madison, WI, USA.

Stoops, G., Marcelino, V., 2018. Lateritic and bauxitic materials. [In:] Stoops, G., Marcelino, V., Mees, F. (Eds.), Interpretation of Micromorphological Features of Soils and Regoliths. Elsevier, Amsterdam, pp. 691-720. https://doi.org/10.1016/B978-0-444-63522-8.00024-3

Thomas, G.W., 1996. Soil pH and Soil Acidity. [In:] D.L. Sparks et al. (Eds.) Methods of Soil Analysis. Part 3. Chemical Methods - SSSA Book Series no. 5. SSSA and ASA, Madison, WI, USA, pp. 475-490. https://doi. org/10.2136/sssabookser5.3.c16

Torrent, J., Nettleton, W.D., Borst, G., 1980. Clay illuviation and lamellae formation in a psammentic Haploxeralf in southern California. Soil Science Society of America Journal 44, 363-367. https://doi. org/10.2136/sssaj1980.03615995004400020031x

Uziak, S., Poznyak, S., Wyszniewskij, J., 2010. Soils of Roztocze. Annales Universitatis Mariae Curie-Skłodowska 65(1), 99-115. https://doi. org/10.2478/v10066-010-0022-4

Van Reeuwijk, L.P., 2002. Procedures for Soil Analysis. International Soil Reference and Information Centre Technical Paper 9. Wageningen.

Van Reeuwijk, L.P., de Villiers, J.M., 1985. The origin of textural lamellae in Quaternary coast sands of Natal. South African Journal of Plants and Soils 2, 38-44, https://doi.org/10.1080/02571862.1985.10634137

Wilson, M.A., Righi, D., 2010. Spodic materials. [In:] Stoops, G., Marcelino, V., Mees, F. (Eds.), Interpretation of Micromorphological Features of Soils and Regoliths. Elsevier, Amsterdam, 251-273. https://doi. org/10.1016/B978-0-444-53156-8.00012-X 
Geneza, właściwości i transformacja lamelli w glebach rdzawych

południowo-wschodniej Polski

\section{Słowa kluczowe}

Gleby piaszczyste Poziom siderik

Geneza gleb

Mikromorfologia

Iluwiacja

\section{Streszczenie}

Lamelle są formą iluwialnego nagromadzenia frakcji iłowej powszechnie występującą w piaszczystych utworach czwartorzędowych. Pomimo dużego zainteresowania badaniem gleb, w których lamelle występują wciąż nie jest w pełni rozpoznana geneza, właściwości i transformacja lamelli. Dodatkowo, badania nad lamellami w piaszczystym materiale przeprowadzane były głównie w glebach bielicowych, ochrowych oraz w arenosolach, natomiast brakuje badań prowadzonych pod tym kątem w glebach rdzawych. Głównym celem badań było wyjaśnienie genezy lamelli oraz ich transformacji w glebach rdzawych (Brunic Arenosols) południowo-wschodniej Polski na podstawie ich morfologii i właściwości fizycznych i chemicznych z wykorzystaniem badań mikromorfologicznych. Badania przeprowadzono na obszarze południowo-wschodniej Polski (Brama Krakowska oraz Pogórze Środkowobeskidzkie), na stanowiskach badawczych: Kostrze, Gołęczyna i Połomia. Materiałem macierzystym badanych gleb są piaski fluwioglacjalne. Lamelle glebowe w badanych glebach rdzawych wykazują duże zróżnicowanie pod względem morfologii oraz właściwości fizyko-chemicznych. Charakteryzują się wyższą zawartością drobnych frakcji $(<0,05 \mathrm{~mm})$, węgla organicznego oraz pedogenicznych form żelaza i glinu $\mathrm{w}$ porównaniu $\mathrm{z}$ interlamellami. Szereg cech morfologicznych oraz mikromorfologicznych, takich jak m.in. obecność i wykształcenie ilastych i ilasto-żelazistych otoczek na ziarnach kwarcu jest dowodem na pedo-petrogeniczną genezę tych form. W ujęciu profilowym zwraca uwagę fakt, że w stropowych częściach gleb rdzawych lamelle wykazują duży stopień zdegradowania spowodowany przede wszystkim aktywnością biologiczną. Z kolei w poziomach BC i materiale macierzystym są bardzo dobrze wyrażone i charakteryzują się wzmożoną ekspresją. 